\title{
COLLECTIVE INDIVIDUALISM: \\ DECONSTRUCTING THE LEGAL CITY
}

\author{
GeORGETTE C. POINDEXTER $†$
}

\section{TABLE OF CONTENTS}

INTRODUCTION .608

I. REVEALED PREFERENCE FOR THE SUBURBS

TRANSFORMED INTO STYLISTIC FACT

A. Economic Motivation for Suburban Shift...............................613

B. Political/Legal Motivation for Suburban Shift ........................616

C. Social Motivation for Suburban Shift ................................. 618

D. Suburban Shift as Self-Definition in the Creation

of the Collective Individual.

II. THE MOlding of Political Power AROUND

THE COLLECTIVE INDIVIDUAL

A. Housing vs. Schools-Gautreaux,

Milliken and Their Progeny

B. Annexation and Other Manipulations of

Municipal Boundaries...

C. Local Governments and Voting Rights..................................634

III. THE COLLECTIVE INDIVIDUAL AND MORAL HYPERNORMS .............635

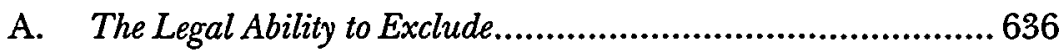

B. Limitations on the Ability to Exclude .................................639

1. Necessity of State Action ..............................................639

2. Abandoning the State Action Requirement...................641

3. Limits on State Intervention .........................................646

IV. THE STRUGGLE TO RESTRUCTURE LOCAL GOVERNMENT................648

A. The Neighborhood as a Political Entity................................ 649

† Citibank Term Assistant Professor of Real Estate and Legal Studies, Wharton School, University of Pennsylvania; Assistant Professor of Law, University of Pennsylvania Law School. Thanks to the Annenberg Dubois Policy Fellowship and to the Wharton Real Estate Center for financial support of this research. The author thanks Regina Austin, Richard Briffault, Tom Dunfee, Susan Friewald, Peter Linneman, Ken Shropshire and Bill Tyson for their very helpful comments on an earlier draft. Thanks also to the participants in the Legal Studies/Real Estate Brown Bag discussions. Thanks to Jerry Frug and Alan Strudler for helpful discussions on this project. Of course, any errors remaining are solely mine. 
B. Constructing the Political Neighborhood ................................653

V. POLITICAI REALITY AND SOCIAI JUSTICE.......................................656

A. Paradox of a Collective Choice Democracy.............................657 657

1. The Individual Within the Political Neighborhood .....658

2. The Individual Within the Region..................................660

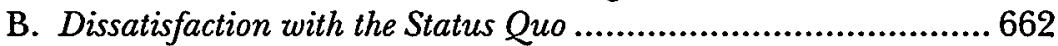

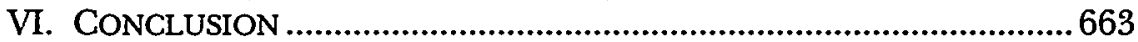

The true meaning of the word "City" has been almost entirely lost by the moderns, most of whom think that a Town and a City are identical, and that to be a Burgess is the same thing as to be a Citizen. They do not know that houses may make a town, but that only citizens can make a City.

-Rousseau ${ }^{1}$

\section{INTRODUCTION}

The dialogue begun by Professor Gerald Frug ${ }^{2}$ and taken up in many subsequent articles, ${ }^{3}$ invites us to construct the Legal City. In

'Jean-Jacques Rousseau, The Social Contract, in SOCIAL CONTRACT: ESSAYS BY LOCKE, HUME, AND ROUSSEAU 169, 181 n.5 (Oxford Univ. Press 1962) (1762).

2 See Gerald E. Frug, The City as a Legal Concept, 93 HARV. L. REV. 1057, 1059 (1980) (explaining the law's contribution to "the current powerlessness of American cities").

${ }^{3}$ See, e.g., Richard Briffault, Our Localism: Part I-The Structure of Local Government Law, 90 Colum. L. REv. 1, 4 (1990) [hereinafter Our Localism: Part I] (providing a critical reading of the "law of state-local relations"); Richard Briffault, Our Localism: Part II-Localism and Legal Theory, 90 CoLUM. L. REV. 346 (1990) [hereinafter Our Lo calism: Part II] (describing interlocal differences and setting forth a normative account of local power); Richard Briffault, Voting Rights, Home Rule and Metropolitan Governance: The Secession of Staten Island as a Case Study in the Dilemmas of Local SelfDetermination, 92 COLUM. L. REV. 775, 779 (1992) [hereinafter Voting Rights] (arguing that the fragmentation of cities such as New York creates "serious ... economic, political, and social concerns"); Richard Briffault, Who Rules at Home?: One Person/One Vote and Local Governments, 60 U. CHI. L. REV. 339, 343 (1993) [hereinafter Who Rules at Home?] ("The encounter between one person/one vote and American local governments ... tells us something about both the uncertain conceptual underpinnings of our dominant conception of representation and the multiple roles local governments play in American life."); Richard T. Ford, The Boundaries of Race: Political Geography in Legal Analysis, 107 HARV. L. REV. 1841, 1845 (1994) ("[R]acially identified space results from public policy and legal sanctions-in short, from state action-rather than being the unfortunate but irremediable consequence of purely private or individual choices."); Jerry Frug, Decentering Decentralization, 60 U. CHI. L. REV. 253, 254 (1993) (rejecting the "traditional understanding of decentralized power in America"); Joan C. Williams, The Constitutional Vulnerability of American Local Government: The Politics of City Status in American Law, 1986 WIS. L. REV. 83, 86-87 (1986) (discussing "the current impact of the constitutional vulnerability of cities" and Frug's use of "the issue of city status as a proxy for his fears and aspirations about governmental power"). 
these works the city as a legal entity is viewed either vis-à-vis its inhabitants or in relation to higher forms of government. The emphasis has been on the law's role in justifying, defending and criticizing existing lócal government.

I propose that we deconstruct the Legal City and view the existence of the city, in fact all of local government, as a manifestation of revealed choice based on the collective individualism of its citizens. I define collective individualism as spatially delineated individual expressions of self that are aggregated into community definition. Instead of beginning with a legal structure-local government-to explain economic results (such as income disparities between cities and suburbs), we need to begin with economic realities (such as people searching for their ideal local community), and craft legal structures to support these realities. We need to validate consumers' individualism and revealed choice by dissolving legal impediments to the full and free expression of their choice.

Economic, legal and social agendas compel the deconstruction of the Legal City. On the legal front, municipal government is, and historically has been, of uncertain status. ${ }^{4}$ Its status is indeterminate due, in no small part, to competing and diametrically opposed views of the source of local legal power. Is the city autonomous or a mere arm of the state? Until we peel back the layers of doctrine imposed by these conflicting ideas of municipal government to expose the true nature of local government power-which, I submit, is premised on the power of the collective individual-the legal status of the city will continue to flounder.

Deconstruction of the Legal City is further necessitated by harsh economic reality. Problems of poverty, crime and social welfare of urban centers continue to occupy the domestic agenda of the United States. However, as the population (most notably the middle-income population) shifts away from the city to the suburbs, the economic ability to rectify city-centered problems often lies in the hands of those people least likely to live in the city. ${ }^{5}$ Increasingly, regional economic power has moved to the suburbs while regional social problems have remained in the city. The result is a seemingly never-ending search for

\footnotetext{
4 See infra notes 82-86 and accompanying text.

' In 1987 the per capita income of city residents was $59 \%$ of their suburban neighbors. Some cities fared even worse. For example in Philadelphia in 1990, the city per capita income was $48 \%$ of the suburban per capita income. See Georgette C. Poindexter, Towards a Legal Framework for Regional Redistribution of Poverty-Related Expenses, 47 WASH. U. J. URB. \& CONTEMP. L. 3, 10 (1995).
} 
legal methods that permit city leaders to tap suburban wallets to solve inner city problems.

Finally, we must confront the problem of determining the social morality of a political community, such as a city. In a nation founded and premised upon an exaltation of heterogeneity, is there room for validation of homogeneity? Deconstruction of the Legal City based on collective individualism may push counter to the almost sacrosanct social goals of racial and ethnic integration ${ }^{6}$ and inclusionary zoning. ${ }^{7} \mathrm{Al}-$ though a frank discussion of the legitimacy of these goals may be politically difficult, blind acceptance of these goals without debate produces a political structure with the weakest of normative underpinnings. The moral goals of the creation of a political community should not be assumed.

The starting point for deconstruction is a critical examination of demographic facts. The massive middle class shift to the suburbs and away from the city is a most certain reality. Calls for regional governance, once in vogue, ${ }^{8}$ have reappeared." However, whether due to myopia or to calculated disregard for the reality of America's shift to the suburbs, advocates of regionalism fail to see the obvious: America's middle class has left the city for the suburbs. This exodus exhibits a revealed preference for life outside the city. Suburbanites view calls for regional government as thinly veiled ruses for sucking them (and their wallets) back into the system from which they fled. Regional government does not question whether the present system of local government meets the needs of modern political society. In fact, it does just the opposite. Although regional government may respond to problems of transportation and revenue sharing, it does not respond to the criti-

6 See, e.g., Fair Housing Act, 42 U.S.C. $\$ \S 3601-3631$ (1994).

7 See, e.g., Southern Burlington County NAACP v. Township of Mount Laurel, 336 A.2d 713, 724 (N.J. 1975) (Mount Laurel I) ("Every... municipality must, by its land use regulations, presumptively make realistically possible an appropriate variety and choice of housing."); Southern Burlington County NAACP v. Township of Mount Laurel, 456 A.2d. 390, 410 (N.J. 1983) (Mount Laurel II) (clarifying and strengthening the original decision in Mount Laurel I); Hills Dev. Co. v. Township of Bernards, 510 A.2d 621, 654 (1986) (Mount Laurel III) (reinforcing the commitment to "the provision of a realistic opportunity for the construction of needed lower income housing").

${ }^{8}$ See, e.g., Robert C. Wood, A Division of Powers in Metropolitan Areas, in AREA AND POWER: A THEORY OF LOCAL GOVERNMENT 53, 55 (Arthur Maass ed., 1959) ("Finally, and happily, perhaps, there appears to be a readiness to experiment with new structures of government ....").

${ }^{9}$ See, e.g., DAVID RuSK, CITIES Wrthout Suburbs 85 (1993) ("The 'city' must be redefined to reunify city and suburb. Ideally, such reunification is achieved through metropolitan government."). 
cal need for an economic, political or social basis for creation of a political community.

Instead of fighting the strong current of revealed consumer preference, we should use that preference as the basis for empowering local government. That which strengthens revealed choice will be implemented. That which impedes the quest for individualism will be discarded. Instead of attempting to convince those who have left the city (both businesses and residents) that it is in their best interest to care about the city that they left behind, the law should validate their locational decisions by strengthening the independence of individual communities. A region's citizens cannot be melted into one big regional pot without ignoring the differing mixes of taxes, services and social desires of individuals within the region.

This argument, however, is not a wholesale adoption of Charles Tiebout's theory of public choice. ${ }^{10}$ The fragmentation of local government produces significant externalities that cannot be assumed away. Just as calls for regionalism are myopic, sole reliance on individual choice ignores the accompanying externalities. Acknowledging the middle-class move to the suburbs as a revealed preference does not help solve the problem of poverty left behind in the cities. For that we must fashion a mechanism that internalizes the externalities.

I propose that the Legal City be dismantled in two stages. First, remove the barriers to expression of individual choice to allow all residents the opportunity to create the community that they desire. Neighborhoods would be free to secede from their existing jurisdiction without externally imposed limitations so as to form the community that they seek. It is here that we must confront the social and moral limitations on community selection. To what extent should a community be allowed to "define" itself? Is economic segregation permissible but racial and ethnic discrimination impermissible? The answer lies in the discovery of community hypernorms that will serve as the moral compass for community formation. Hypernorms are those normative values so fundamental to human existence that they have universal application.

There will, however, be people who have neither the political savvy nor the economic independence to declare their freedom from City Hall. By default, and by choice, some neighborhoods will remain

${ }^{10}$ See Charles M. Tiebout, A Pure Theory of Local Expenditures, 64 J. POL. ECON. 416, 424 (1956) ("If consumer-voters are fully mobile, the appropriate local governments, whose revenue-expenditure patterns are set, are adopted by the consumer-voters."). 
within the geographic and political boundaries of what was once the "city." To address the externalities associated with such legal dissection, the second part of the deconstruction sets up an intermediate tier of local government to engage solely in wealth redistribution. Such a redistribution would be region-wide-not the more commonly feared suburb-to-city flow of money.

Part I of this Article introduces the concept of American consumers' revealed preference for the suburbs. It explores the stylized fact that Americans, in general, prefer the suburbs to the city. This Part explores the reasons why suburbs are growing in population while the central cities are shrinking. Part II discusses the ways in which the present system of local government law affects this revealed preference of community choice by building walls between the city and its suburbs while simultaneously rejecting local attempts at economic and political isolation. In Part III, the moral and normative bases of community are analyzed to shape a working model of community values. Part IV synthesizes the preceding discussion by exploring ways to restructure American local government in an attempt to combine a validation of collective individualism with a legitimate normative base, while creating a wealth redistribution plan that would benefit the entire region. Part $\mathrm{V}$ concludes the discussion by fitting the new model within the confines of political reality and social justice.

\section{REVEALEd PREFERENCE TRANSFORMEd INTO STYLIZEd FACT}

Do what you may, there is no true power among men except in the free union of their will.

-Alexis de Tocqueville ${ }^{11}$

The shift of America's population away from the city and to the suburbs is a stylized fact. ${ }^{12}$ Although it is beyond the scope of this dis-

$"$ Alexis DE ToceueVlle, DEMOCRACY in AMERICA 69 (Richard D. Heffner ed., 1956).

Stylized facts are empirical regularities that describe the most obvious features of a dynamic system. See generally MICHAEL REITER, THE DYNAMICS OF BUSINESS CYCLES: STYLIZED FACTS, ECONOMIC THEORY, ECONOMETRIC METHODOLOGY AND APPLICATIONS 9-12 (1995). A stylized fact requires an analytical model to explain its existence. For example, assume that women earn $60 \%$ of the wages earned by men. The existence of this fact requires a theoretical explanation, such as discrimination, lower productive ability or genetic differences. In a discussion using stylized facts, the validity of the statistic is accepted as fact. See Charles W. Calomiris, The Motivations for Loan Commitments Backing Commercial Paper, 13 J. BANKING \& FiN. 271, 271 (1989) (discussing a model that explains "the 'stylized fact' that firms with a high percentage of backing for 
cussion to prove this fact statistically, some numbers are in order to convince the nonbeliever. In 1940, over one-half of Americans lived in rural areas; more than twice as many lived in the central cities of metropolitan areas as lived in the suburbs. ${ }^{18}$ By 1970 , the suburbs had surged ahead and, for the first time, had a greater population than either the cities or rural areas. ${ }^{14}$ The suburban steam engine continues to roll. We have entered the "suburban century" in politics, ${ }^{15}$ when almost half of the American population now lives in the suburbs.

Relative loss of population to the suburbs is not solely a problem of the nation's largest cities. Overall population density in America's 522 central cities has declined from 5,873 persons per square mile in 1950 to 2,937 persons per square mile in $1990 .^{16}$ In 1950 , there were thirtyeight cities with population density greater than 10,000 or more persons per square mile. By 1990, there were only fifteen cities that were that dense. ${ }^{17}$

If the nonbeliever is still not convinced of the stylized fact of America's move to the suburbs, a quick check of regional dominance should persuade her. In the 1950s, fifty-seven percent of people residing in major metropolitan areas lived in the central city and forty-three percent lived in the suburbs. ${ }^{18}$ By 1990, however, the city's share of the metropolitan population plummeted to thirty-seven percent and the suburban share increased to sixty-three percent. ${ }^{19}$

Although the shift away from the city to the suburbs can easily be seen statistically, understanding the economic, political, legal and social ramifications requires a more in-depth analysis. Statistics describe how the population shifts; what is missing is the why.

\section{A. Economic Motivation}

An economic explanation for the shift to the suburbs follows from

their commercial paper tend to have high commercial paper ratings."); Brian $\mathrm{H}$. McGavin, The Political Business Cycle: A Reexamination of Some Empirical Evidence, 26 Q.J. Bus. \& ECON. 36, 36 (1987) ("The political business cycle usually is accepted as a stylized fact of democratic industrial countries.").

13 See Jerry Adler, Bye Bye Suburban Dream, NEwSwEEk, May 15, 1995, at 41.

${ }^{14}$ See id.

${ }^{15}$ William Schneider, The Suburban Century Begins, THE ATLANTIC, July 1992, at 33.

${ }^{16}$ See RuSK, supra note 9 , at 8.

${ }^{17}$ See id.

${ }^{18}$ See Peter Mieszkowski \& Edwin S. Mills, The Causes of Metropolitan Suburbanization, J. ECON. PERSP., Summer 1993, at 135.

${ }^{19}$ See id. 
the work of Charles Tiebout. ${ }^{20}$ Simply stated, the Tiebout hypothesis contends that a consumer searches within the region for the municipality that best satisfies her optimal mix of services and taxes. ${ }^{21}$ Just as a consumer chooses between supermarkets based on service and price, so does she choose among municipalities. Spatial mobility-the ability to move one's residence-provides the local public-goods corollary to the private-market trip." "There is no way in which the consumer can avoid revealing his preferences in a spatial economy. ${ }^{23}$

Although perhaps valid in other situations, criticisms of the Tiebout model (such as informational barriers, assumption of cost-neutral choice and absence of racial/ethnic barriers) ${ }^{24}$ are inapplicable in the present context. Application of the Tiebout hypothesis here only requires comparison between the city and its suburbs-not among suburbs themselves. Individual suburbs are fungible in a city-versussuburbs decision tree. Reduction of the decision tree to two branches, however, should not obliterate the impact of local government fragmentation on revealed choice. Although our consumer is choosing between the city and suburbs, her choice is enhanced by the existence of

${ }^{20}$ See Tiebout, supra note 10, at 418; see also CHARLES L. LEVEN \& JONATHAN MARK, A REVEALED PREFERENCE MODEL FOR ANALYZING INTERNEIGHBORHOOD MOBILITY 1 (Institute for Urban \& Reg'l Studies, Wash. U., Working Paper HMS 6, 1975) (suggesting several "hypotheses why people move between neighborhoods"); Bruce W. Hamilton, Property Taxes and the Tiebout Hypothesis: Some Empirical Evidence, in FISCAL ZONING AND LAND USE CONTROLS 13, 14 (Edwin S. Mills \& Wallace E. Oates eds., 1975) (criticizing Tiebout for his failure to "endow his mechanism with a system of prices for the local public services"); Robert P. Inman \& Daniel L. Rubinfeld, The Judicial Pursuit of Local Fiscal Equity, 92 HARV. L. REV. 1662, 1669 (1979) ("A family deciding where to locate within a metropolitan area will search for a community that provides that bundle of municipal services and housing which most closely approximates its preferred package.").

${ }_{21}$ See Tiebout, supra note 10, at 418; see also Steven L. Percy et al., Revisiting Tiebout: Moving Rationales and Interjurisdictional Relocation, 25 PuBLIUS, Fall 1995, at 1, 10 (analyzing interjurisdictional moves in Milwaukee in 1992 and concluding that "tax and service factors are used more often in selecting a new residence").

${ }_{22}$ See Tiebout, supra note 10 , at 422 .

$2 \mathrm{~s} I$.

24 See Harold A. McDougall, Regional Contribution Agreements: Compensation for Exclusionary Zoning, 60 TEMP. L.Q. 665, 667-68 (1987) ("[T]he value of Tiebout's thesis appears of limited value in the context of exclusionary zoning."); Wallace E. Oates, On Local Finance and the Tiebout Model, 71 AM. ECON. REV. 93, 93 (AEA Papers \& Proceedings 1981) (suggesting that the Tiebout model "involves a set of assumptions so patently unrealistic as to verge on the outrageous"); Stewart E. Sterk, Competition Among Municipalities as a Constraint on Land Use Exactions, 45 VAND. L. REV. 831, 834 (1992) (explaining "why market forces are inadequate to eliminate the potential for municipal abuse of the exaction process"). 
several varied local governments from which she may pick. ${ }^{25}$

Empirical data, in fact, bear out the Tiebout hypothesis. Consumers do choose between the city and the suburbs based upon a bundle of taxes and services. Middle-class migration between the city and the suburbs is significantly related to two salient differences between city and suburbs: (1) taxes and (2) spending for education. ${ }^{26}$ In effect, a consumer's move to the suburbs is a revealed preference for that community's bundle of goods and services. To place this theory in context, the movement to the suburbs shows that consumers are not buying what the city has to offer. Being rational economic customers, they are buying the product that best serves their needs; that product just happens to be located in the suburbs. Suburban governments compete for citizens who contribute more in taxes than they consume in services to maintain this competitive advantage.

Revealed preference is premised upon consumers' rational choice between alternatives, a choice that is based on welfare maximization. Paul Samuelson's "Weak Axiom of Revealed Preference" states that "if an individual selects batch one over batch two, he does not at the same time select two over one."27 In other words, selection of one location is a rejection of all other locations. In choosing a location, the consumer reveals her preference for that location. ${ }^{28}$ This choice, though, is made

${ }^{25}$ Fragmentation allows municipalities to include, or exclude, residents in accordance with the wishes of the municipality through zoning ordinances, also known as exclusionary zoning. See Stephen D. Galowitz, Interstate Metro-Regional Responses to Exclusionary Zoning, 27 REAL PROP. PROB. \& TR. J. 49, 61 (1992) (suggesting that a desire to increase housing prices is an incentive to exclude). This concept, however, goes deeper than zoning ordinances. Beyond the law there is evidence that interjurisdictional differences in tax rates and public sector benefits are capitalized into residential property values. See Bruce W. Hamilton, Capitalization of Intrajurisdictional Differences in Local Tax Prices, 66 AM. ECON. REv. 743, 743 (1976) (developing a model in which "the excess of local public sector benefits over tax liability (or fiscal surplus) causes shifts in the demand curves for various classes of residential property").

${ }^{26}$ See Vicki Been, "Exit" as a Constraint on Land Use Exactions, 91 COLUM. L. REV. 473,524 (1991) ("Many studies have shown that middle-class migration between the city and the suburbs is significantly affected by the disparity between city and suburban spending for education."); Percy, supra note 21, at 13, 14 (noting that taxes and the quality of public schools are significant predictors of cross-community relocations).

${ }^{27}$ Paul A. Samuelson, A Note on the Pure Theory of Consumer's Behaviour, ECONOMICA, February 1938, at 61, 65 (with errata, August 1938).

${ }^{28}$ A theoretical difficulty with Samuelson's theory is that it supposes only two alternatives. Kenneth Arrow relaxed the Samuelson framework in two ways: he allowed for the possibilities 1) that there were more than budget sets involved in the choice and 2) that consumers could have more than one "best" alternative when faced with a set. KENNETH J. ARROW, SOCIAL CHOICE AND INDIVIdUAL VALUES 46 (1951). Arrow set forth the "Impossibility Theorem," which questions the ability to make collective deci- 
as a result of consumers' attempts to maximize wealth. ${ }^{29}$ It is fundamental that, if given a choice, a consumer "selects the alternative which yields the greatest welfare. ${ }^{\text {s0 }}$

The economic explanation presents the consumer with a choice between living in the city and living in the suburbs. Leaving aside the myriad of choices among suburbs, the consumer will compare the economic advantages and disadvantages of the suburbs with those of the city in an attempt to maximize her wealth. Because cities are generally burdened with higher taxes, older infrastructure and weaker services (especially public education), the rational (and economically independent) consumer will choose the suburbs. ${ }^{31}$

\section{B. Political/Legal Motivation}

The political impetus for the move to the suburbs may be the desire to have a meaningful voice in participatory democracy. A citizen must count herself as a consensual member of the community if democracy, based on majority rule, is truly to exist. As Rousseau stated:

The undertakings which bind us to the Commonwealth are obligatory only because they are mutual.... For how can the general will be always right, and how can all constantly will the happiness of each, if every single individual does not include himself in that word each, so that in voting for the general interest he may feel that he is voting for his own? ${ }^{32}$

To borrow Hannah Arendt's idea of freedom, local government responds to a citizen's need "to participate actively in the basic societal

sions because social choice is an aggregation of individual preferences. Id. Just as Condorcet proved, collective decisionmaking is impossible when more than two alternatives are presented. For a description of the Condorcet paradox, see Maxwell L. Stearns, Standing Back From the Forest: Justiciability and Social Choice, 83 CAL. L. REV. 1309,1329 (1995) (describing the decisionmaking process of law review editors in the selection of one article for publication when faced with three possible choices). Because we are dealing only with a choice between the city and the suburb, Arrow's theory is inapplicable.

${ }^{29}$ This means that a consumer will choose alternative $x$ over alternative $y$ if $W(x) \geq$ W(y). See KAUSHIK BASU, REVEALEd PREFERENCE OF GOVERNMENT 59 (1980).

so $I$.

31 This assumption should not imply that those consumers living in the city are irrational. There are those who choose to live in the city because the services provided (including culture and commerce) mesh with their individual choice. Furthermore, there are those who live in the city because they cannot afford the suburbs. In the former case, the city consumer's choice is rational decisionmaking in the same manner as those who choose the suburbs. In the latter case, the consumer's "choice" is not irrational, but rather made in response to market constraint.

32 Rousseau, supra note 1, at 196. 
decisions that affect one's life." At the risk of "mobiliz[ing] resonant Jeffersonian imagery," the political process underlies the very existence of a democratic government. ${ }^{35}$ The smaller the political community, the more likely a resident will see an impact of her political voice. Furthermore, the greater impact a resident feels her voice has, the more likely she will be to use it. $^{36}$

In her desire to have an impact, a consumer looks for a government where her political voice will not be drowned in a sea of dissent. She seeks smaller and more homogeneous political communities. At some point, the size of local governments may dip below the minimum size capable of providing all the necessary services. ${ }^{37}$ Size of community, however, is not only an outcome of the consumer's choice, but also a factor in that choice. A consumer looks for political impact, but there is also an implicit willingness to trade personal political power for the desired mix of services.

Political motivations, however, go beyond a romantic view of participatory democracy. A real division of governmental power throughout communities in the region "may contribute to the fundamental objectives of a modern democratic state" including "liberty, equality and welfare." ${ }^{\text {,38 }}$ Some commentators contend that smaller governments

${ }^{\text {ss }}$ Frug, supra note 2, at 1068 (citing HANNAH ARENDT, ON REVOLUTION 114-15, 119-20 (1962) and discussing Arendt's concept of "public freedom").

${ }^{34}$ Williams, supra note 3 , at 105 .

${ }^{35}$ See Letter from the Federal Farmer to the Republican (Oct. 12, 1787), in THE AMERICAN CONSTITUTION FOR AND AGAINST 33-34 (J.R. Pole ed., 1987) ("[W] hen power is transferred from the many to the few, all changes become extremely difficult....").

${ }^{95}$ For a discussion of the intersections of exit, voice and loyalty, see ALBERT O. HIRSCHMAN, EXIT, VOICE, AND LOYALTY (1970).

${ }^{57}$ See Voting Rights, supra note 3 , at 828 (discussing a solution to this size problem). Political theorists conclude that a neighborhood should range from 50,000 to no more than 200,000 inhabitants to maximize democratic participation. See, e.g., Robert Dahl, The City in the Future of Democracy, 61 AM. POL. SCI. REV. 953, 967 (1967) (suggesting that the "optimum size for a city [is] the range... from 50 thousand to about 200 thousand"); Douglas Yates, Neighborhood Government, in NEIGHBORHOODS IN URBAN AMERICA 131, 138 (Ronald H. Bayor ed., 1982) ("Democratic theorists argue that a city ... should probably contain no more than 200,000 residents if anything remotely like direct democracy is to exist." (emphasis omitted)). I submit that the ideal size is closer to 50,000 for social reasons.

${ }^{38}$ Wood, supra note 8, at 53 (describing the views of Ylvisaker regarding the ends served by an areal division of power); see also Big Country Foods, Inc. v. Board of Educ., 952 F.2d 1173, 1179 (9th Cir. 1992) ("[L]ocal control fosters both administrative efficiency and democratic governance."); Voting Rights, supra note 3, at 823 ("The debate over the appropriate structure for metropolitan governance has been informed by 
function more efficiently. ${ }^{39}$ The benefit for the consumer, though, is not solely an economic consideration. In her quest for the ideal government, a consumer considers the manner in which government functions. She looks for a government where the decisions will be predictable and orderly. Instead of the normative "should" inquiry of democratic ideals and political participation, the consumer's functional analysis focuses on the instrumental "how."

Such a functional analysis of local government is certainly not new. ${ }^{40}$ Functional analysis, however, permits us to analyze local government choice not only as choice between political goals but also as choice between political systems. Governmental structure is not an incidental by-product of local government. Just as procedural and substantive law are crucial to litigation, so too are structure and policy central to choice of a political community. Is the structure removed from the people (e.g., strong mayor)? Is power diffuse (e.g., weak mayor with strong local council)? The mode of government is as important as the manner.

The political impetus behind the shift to the suburbs can thus be traced to the search for a meaningful voice in the political process. The consumer can feel the importance of her voice satisfying the desire for political impact and participation. Furthermore, the functional structure of the government matters. In contrast to the hulking bureaucracy of many large city governments, suburban governments are smaller and, perhaps, more personal. The political explanation for the shift to the suburbs rests on the consumer's pursuit of these two goals.

\section{Social Motivation}

Scholars cite many social factors behind the move to the sub-

concerns for efficiency, equity, and democracy.").

${ }^{39}$ See, e.g., Our Localism: Part II, supra note 3, at 402 (noting the view of some urban economists that interlocal competition between fragmented and overlapping local governments promotes efficiency); Richard Briffault, The Role of Local Control in School Finance Reform, 24 CONN. L. REV. 773, 791 (1992) ("Economists have suggested that economies of scale turn into diseconomies once a government unit grows past a certain size."); $c f$. Steven C. Deller, An Application of a Test for Allocative Efficiency in the Local Public Sector, 20 Regional SCI. \& URB. ECON. 395, 406 (1990) ("[A] higher level of fragmentation in local public good provision is positively capitalized into total property values.").

${ }^{40}$ For an historical analysis of the links between the functional requirements of government and governmental spatial reform, see Wood, supra note 8, at 59 . 
urbs, including racial strife, ${ }^{41}$ housing styles, ${ }^{42}$ proximity to work via new interstate highways ${ }^{43}$ and government-subsidized mortgages. ${ }^{44}$ These social motivations inject the serendipity of human nature and personality into our discussion. When a consumer chooses among an array of local government choices she makes more than a political or economic choice. The consumer chooses a lifestyle and gives in to the natural human tendency toward social factionalization. David Hume, the Scottish philosopher, discussed the natural tendency for humans to separate into factions: "Men have such a propensity to divide into personal factions that the smallest appearance of real difference will produce them. ${ }^{45}$

The social consequence of choice is that communities "possess[] a moral as well as a physical organization, and these two mutually interact in characteristic ways to mold and modify [each other]. ${ }^{46}$ If commu-

41 See Carolyn ADAMS et al., Philadelphia: Neighborhoods, DIVISION, AND CONFLICT IN A POSTINDUSTRIAL CITY 83 (Joe T. Darden ed., 1991) (describing "white flight" from the city of Philadelphia). But see LEVEN \& MARK, supra note 20, at 3 ("[The] median income of its population, not racial composition, is the most relevant neighborhood characteristic in determining the willingness to pay for, a particular unit."); Georgette C. Poindexter, Locational Perception: City Versus Suburban Home Buying Preference, 16 LAW \& POL'Y 473, 481 (1994) (questioning the "importance of racial homogeneity as a primary motivational factor" in the move to the suburbs).

${ }^{42}$ See Poindexter, supra note 41 , at 480 (finding that style of home is the most important factor affecting suburban residents' choice of neighborhood); see also

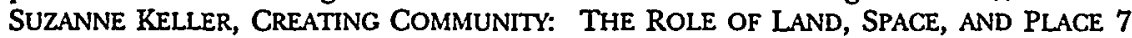
(1986) (noting a significant increase in the number of homeowners who mentioned a detached house as a significant ingredient of an ideal community).

${ }^{13}$ The interstate highway system funded by the federal government provides a web of roads that facilitates travel between the city and the suburbs, allowing workers to live in the suburbs while working in the city. See Brian J. O'Connell, The Federal Role in the Suburban Boom, in SUBURBIA RE-EXAMINED 183, 187-88 (Barbara M. Kelly ed., 1989).

${ }^{44}$ The Federal Housing Authority (FHA) insures home loans to qualified borrowers, thus eliminating the lender's risk and providing lenders with an incentive to make mortgage loans. In the post-World War II period, however, FHA lending criteria resulted in a pronounced preference in lending for new construction rather than for existing structures. Because new construction tended to be in the suburbs rather than in the city, the program encouraged suburban growth to the detriment of city growth. See id. at 189-90; see also KENNETH T. JACKSON, CRABGRASS FRONTIER: THE SUBURBANIZATION OF THE UNITED STATES 190-218 (1985) (noting that consumer choices were subsidized by federal government policies that pushed people out of the cities while pulling them into the suburbs).

45 DAVID HuME, I ESSAYS: MORAL, POLITICAL, AND LITERARY 128 (T.H. Green \& T.H. Grose eds., London, Longmans, Green \& Co. 1875), quoted in Douglass Adair, That Politics May be Reduced to a Science, 20 HUNTINGTON LIBR. Q. 343 (1957), reprinted in FAME AND THE FOUNDING FATHERS: EsSAYS BY DOUGLAS ADAIR 93, 103 (Trevor Colbourn ed., 1974).

${ }^{40}$ ROBERT EZRA PARK, HUMAN COMMUNITIES: THE CITY AND HUMAN ECOLOGY 16 
nity is our "bulwark against all sorts of alien influences, a sort of security perimeter," then our revealed choice is as much about where we want to be as where we do not want to be. ${ }^{48}$

Why, socially, have Americans chosen the suburbs? The quick answer is tied to racial strife. ${ }^{49}$ Social relations are inevitably correlated with spatial relations. ${ }^{50}$ Because spatial relations in this country have historically been limited by race and ethnicity, ${ }^{51}$ social motivations are imbued with the patina of racial/ethnic exclusion. Hence, a superficial discussion of social motivation leaves much to be desired. Social motivation can imply an element of exclusion that is quite unsettling in a society purportedly striving toward pluralism.

However, the quick answer is not necessarily the complete answer. Although certainly neither denying nor discounting America's history of racial and ethnic housing discrimination, ${ }^{52}$ I submit that our analysis cannot stop at "white flight." Historically, planners and architects attempted to create communities built upon strengthening social relationships. ${ }^{53}$ The ascent of the neotraditional planning movement, with its shared open space and front porches, signals a desire to reconnect

(1952). Park's animation of the city, giving it life, allows us to conceptualize community as an organic being, capable of change from within. Park goes so far as to liken the city to a super-organism as in plant ecology: "[P]lants and animals, living together in a common habitat, invariably tend to develop a natural economy and to form, as an incident of such economic interdependence, a biotic community in which the different species are able to live more securely and prosperously together than they can apart." Id. at 119; see also Phillip L. Clay, Choosing Urban Futures: The Transformation of American Cities, I STAN. L. \& POL'Y REV. 28, 29 (1989) ("It begins with the proposition that cities are organic entities with a capacity for renewal, not just decline.").

${ }^{47}$ GREgORY R. WEIHER, THE FRACTURED METROPOLIS: POLITICAL FRAGMENTATION AND METROPOLITAN SEGREGATION 37 (1991).

${ }^{48}$ For example, the rise in the number of gated communities indicates not only a choice to live in that community, but also an explicit choice to keep other communities separate.

49 See ADAMS ET AL., supra note 41, at 93-98 (“[T] he white population ... despite the presence of a sizable black population in its midst, has managed to maintain its neighborhoods as predominantly white enclaves in both city and suburbs.").

${ }^{30}$ See PARK, supra note 46, at 177 ("[S]ocial status ... turns out finally to be a matter of ... social distance."). A person from the neighborhood is not treated with the same suspicion an outsider engenders when both walk into the neighborhood bar.

${ }^{51}$ Exclusion has been both informal (as in Chinatown, Little Italy and Harlem) and explicit (as in deed restrictions). For a discussion of the formal exclusion, see infra Part III (discussing Shelley v. Kraemer, 334 U.S. I (1947)).

52 See infra Part III (discussing the history of racial and ethnic discrimination in housing).

5s See Suzanne Keller, The Neighborhood, in NEIGHBORHOODS IN URBAN AMERICA, supra note 37, at 8,18 (arguing that planners' justification for designing spatial subdivisions in large urban areas is to "help promote local utilization of services and indirectly encourage other local attachments and loyalties"). 
with our surroundings. ${ }^{54}$

The move to the suburbs is an attempt to find a comfortable social situation. ${ }^{55}$ Call it the "good life" or the "clean life," people are looking for the house with the yard in a safe neighborhood. ${ }^{56}$ Parents' concern for the health and safety of their children motivates them to move to the suburbs. As one urban planner has noted:

Children are like the canaries in the coal mine: an indicator species of urban health. Children are small and vulnerable and need to be protected. If a city lacks children, then it is because parents have assessed the environment and have decided ... to remove to a safer place. But where parents won't raise children, we might all hesitate to live, for such a place presents an environment uncomfortable, noisy, and dangerous. ${ }^{57}$

\section{Suburban Shift as Self-Definition in the Creation of the Collective Individual}

Community choice, then, depends on: (1) affordable services; (2) a government in which an individual has a voice and that functions according to expectation; and (3) a community in which the consumer feels socially comfortable. In effect, revealed preference is intimately bound up with the search for self. Our economic, political and social motivations for seeking community are all related to finding geographic and spatial harmony with ourselves. We need to connect with our surroundings in order to validate and secure ourselves. The sociocentric side of our development requires that we belong to a commu-

${ }^{34}$ The interesting facet of neotraditional planning is that it attempts to recreate in the suburbs the "neighborhood" feel of the city in days gone by. How ironic that the social connection that people seek is a "city" feel that now is by and large confined to the suburbs.

${ }_{5 \overline{3}}$ See HERBERT J. GANS, THE LeVtTTOWNERS 40 (1967) ("[A]bout 95 percent of [Levittowners] ... hoped for improved individual, family, and social life ...."). But see Howard Pack \& Janet Rothenberg Pack, Metropolitan Fragmentation and Suburban Homogeneity, 14 URB. STUD. 191, 191 (1977) (noting that the extent of homogeneity in Pennsylvania suburbs, as determined by age, education, occupation, income and marital status of head of household, was actually more limited than is generally believed). The authors noted, however, that:

[T] he absence of realised homogeneity casts little light on the validity of the underlying behavioural assumption that a desire to live with others of similar background and circumstance is an important feature of social life. Indeed, such desires may be fundamental but their realisation is limited by a number of complicating factors.

Id.

${ }^{56}$ See KELLER, supra note 42, at 2.

57 DAVD SUCHER, CITY COMFORTS: HOW TO BUILD AN URBAN VILLAGE 65 (1995). 
nity, while our egocentric side demands that this community conform with our definition of self. ${ }^{58}$ Although there may be a tendency to use government at all levels to define the individual, ${ }^{59}$ local governments, through the existence of choice, allow for the fullest expression of self. ${ }^{60}$

A word of caution is in order. We should be careful not to confuse the community's definition of the individual with the individual's definition of the community. ${ }^{\text {.1 }}$ Community definition is the sum of the aggregate individual self-definitions. It changes with the residents of the community. As the community attracts residents, these individuals define the community. ${ }^{62}$ Only by first analyzing the process of individual self-definition can we then explore that of community self-definition. The power of definition rests with the individual; the community is but a reflection of its residents' individualities.

Professor Briffault argues that localism exists when "the interests of local residents [are] the exclusive desideratum of local decision makers." ${ }^{\text {"3 }}$ He further states that localism "leads to an association of the lo-

${ }^{58}$ See Shan Guisinger \& Sidney J. Blatt, Individuality and Relatedness: Evolution of a Fundamental Dialectic, 49 AM. PSYCHOLOGIST 104, 104 (1994) ("[S]ocial interest may be as necessary as self-interest to survival."). A mature sense of self is contingent on interpersonal relationships. On the other hand, the continued development of increasingly mature interpersonal relationships is contingent on mature self-definition. There must be a balanced development of both dimensions. See id. at 109 .

${ }^{39}$ For example, there is certainly national patriotism ("American, and proud of it") and state pride ("Texan").

${ }_{60}$ There are over 86,000 units of local government in the United States. See John Kincaid, Regulatory Regionalism in Metropolitan Areas: Voter Resistance and Reform Persistence, 13 PACE L. REV. 449, 450 (1993) (noting that the existence of 86,692 units of local government has resulted in extreme governmental differentiation, especially within metropolitan areas). Contrast that number with the choice of $\mathbf{5 0}$ state governments.

${ }^{61}$ Professor Ford refers to community self-definition as tautological because of racially restrictive entrance barriers. See Ford, supra note 3, at 1860 ("[A]lthough the governance of ... an association may be democratic in form, it may well not be democratic ... in substance if the initial selection of members was highly exclusive."). I disagree. While the imposition of racially restrictive barriers may serve to entrench and strengthen the status quo in a community, barriers are but a tool used to create the definition. To say that "we are a community of white, upper middle-class, singlefamily homeowners" may be racially and economically exclusionary, but it certainly is not tautological.

62 This is not to imply, however, that community definition can be accomplished only by looking within the community. As Professor Frug has written, "the autonomous individual has to be interested in others, not as a matter of sentimentality or altruism but as a matter of self-interest." Frug, supra note 3, at 274 . Just as the individual will be interested in other individuals, so will the local community be interested in other local communities.

${ }^{63}$ Our Localism: Part II, supra note 3, at 444. 
cality with individual autonomy." ${ }^{\text {"t4 }}$ These definitions put the relevance of the distinction between individual and community decisionmaking into focus. The "community," standing alone, is powerless. It derives its power from the individuals who reside within it. ${ }^{65}$ Hence, the community is a collective individual. The power and limitations of the collective individual constitute the power of the community.

The idea of the community as a collective individual rejects the topdown definition of an inhabitant through her community. For example, during common cocktail chit-chat we often pose the question: Where do you live? The response to the question (city or suburbs, rich neighborhood or poor) defines the respondent. We rarely discover if the individual really is rich or poor; we simply make assumptions based upon her residence. This spatial definition of the individual also occurs in government policymaking. For example, the federal government through its agency, The Home Owners' Loan Corporation, red lined minority neighborhoods. "Red lining" describes the arbitrary denial of loans in certain neighborhoods on the basis of assumptions about the quality of the neighborhood rather than the creditworthiness of the applicant or the nature of the property. ${ }^{66}$ Although loan applicants may have been creditworthy, banks and federal agencies made assumptions about them based upon their neighborhood, preventing loan approval. $^{67}$

Gt $I d$.

${ }^{65}$ This characteristic is the basis of a truly republican government. In discussing the "distinctive characters" of the republican form of government, Madison stated, "we may define a republic to be... a government which derives all its powers directly or indirectly from the great body of the people." THE FEDERALIST No. 39, at 255 (James Madison) (Isaac Kremnick ed., 1987).

${ }^{66}$ See JACKSON, supra note 44 , at 362.

The Home Owners' Loan Corporation (created pursuant to the Home Owners' Ioan Act of 1933, Pub. L. No. 73-43, 48 Stat. 128 (1933)) directed the flow of home mortgage capital. HOLC carved the national housing market into four classifications when it drew up confidential color-coded "Residential Security Maps." Id. at 199. These maps were then used to determine whether credit would be extended to an applicant from a particular neighborhood.

The color-coding system placed a lower value on areas in which Jews, Blacks and other minorities resided. The first category, A or green, was most highly valued. These areas were white, homogenous, desirable neighborhoods. The second group, B or blue, consisted of stable, but declining neighborhoods. The neighborhoods in the third level, $\mathrm{C}$ or yellow, were already in decline, and the fourth, D or red (hence "red lining"), contained the least desirable areas. See id. at 197-98.

Interestingly, the opposite appears to be occurring today. Although people are still defined by their neighborhoods, rigorous enforcement of the Community Redevelopment Act produced a whirlwind of lending activity in historically minority communities. See Jacqueline Simmons, Home Prices Soar in Unexpected Places, WALl ST. J., 
Viewing the community as a collective individual, by contrast, is a bottom-up approach. The community is an agglomeration of individuals. Self-definition of individual inhabitants comes first. The sum of these self-definitions then defines the community. Collective individualism questions our assumption that spatial identity is a proxy for individual identity. To be sure, since people search for themselves in their community, there will continue to be some overlap between community and individual definitions. However, freedom from the strictures of spatial identity allows us to rethink the basis of local government power. Instead of asking what is the power of the community, we need to ask what is the power of the individual, for the power of the collective individual is the power of the community.

\section{The MOlding of Political POWER AROUND THE COLLECTIVE INDIVIDUAL}

As Cato concluded every speech with the words, Carthago delenda est, so do I every opinion, with the injunction "divide the counties into wards. ${ }^{68}$

The decentralized "politics of [local government] boundary creation are uniquely American." In the United States, local governments control the delineation of boundaries. ${ }^{70}$ In contrast, " $[\mathrm{i}] \mathrm{n}$ the United Kingdom, communities wishing to incorporate must petition an agency of national government." ${ }^{\text {"71 }}$ Alexis de Tocqueville traced this desire for decentralized government to our historical pre-Revolutionary equality among citizens. ${ }^{72}$ In a society where revolution is preceded by a relatively egalitarian state, there is a desire for more decentralized government. In contrast, people who have had to struggle for equality prefer a centralized government because a strong central government pre-

Feb. 13, 1996, at A2 ("If it were not for CRA, nobody would be getting these loans, and houses would not be selling at these amounts.").

${ }^{6}$ Richard K. Matthews, The Radical. Politics of Thomas Jefferson: A REVISIONIST VIEW 87 (1984) (quoting Letter from Thomas Jefferson to Joseph C. Cabell (Feb. 2, 1816)).

${ }^{69}$ WEIHER, supra note 47 , at 165 .

${ }^{70}$ This feature is in sharp contrast to other nations where "[u]rban development and local government formation ... are integrated into national policy." Id. For a comparative study of local government structure in 20 Western industrialized countries, see LOCAL GOVERNMENT AND URBAN AFFAIRS IN INTERNATIONAL PERSPECTIVE (Joachim J. Hesse ed., 1990).

${ }^{71}$ WEIHER, supra note 47 , at 3.

72 See DE TOCQUEVILLE, supra note 11 , at 297. Of course, citizens were defined as white male landowners. 
vents a transfer of power to the elite. ${ }^{73}$

The fracturing of local government is a basic concept in American government. Indeed, since the time of the Founding Fathers there has been a search for the optimally sized government for the American people. Because of this distrust of centralized government, Jefferson sought "not to trust it all to one, but to divide it among the many, distributing to everyone exactly the functions he is competent to."74 Jefferson's goal was to "dissolve[] [government] into the unity of society.... [by] republicanism, decentralization, and specialization." ${ }^{75}$ In an attempt to bring government to the people, Jefferson's political wards would form a direct attachment between citizens and their governments and would "attach [the citizen] by his strongest feelings to the independence of his country, and its republican constitution."

The present fractured state of local government, then, should come as no surprise. Its creation was not happenstance, ${ }^{77}$ but rather a deliberate attempt to empower the individual. Perhaps the question of the validity of such fracturing can be explained by exploring the notion that local government, while seeking to protect the individual from the state is, in fact, itself created by the state. Professor Frug calls this relationship among localities, individuals and the state the "principal puzzle confronted by liberal theorists": "Cities were partly creations of the state, yet they were also partly creations of the individuals who lived

${ }^{79}$ See id. De Tocqueville states:

It may be remarked, that, at the present day, the lower orders in England are striving with all their might to destroy local independence, and to transfer the administration from all the points of the circumference to the centre; whereas the higher classes are endeavoring to retain this administration within its ancient boundaries. I venture to predict that a time will come when the very reverse will happen.

Id.

${ }^{74}$ MATTHEwS, supra note 68, at 82 (quoting Letter from Thomas Jefferson to Joseph C. Cabell (Feb. 2, 1816)),

${ }^{75}$ Samuel P. Huntington, The Founding Fathers and the Division of Powers, in AREA AND POWER supra note 8, at 150, 162.

${ }^{70}$ MATTHEWS, supra note 68, at 77 (quoting Letter from Thomas Jefferson to Samuel Kercheval (July 12, 1816)). According to Federalists such as Madison who viewed a large republic as a surer bastion of liberty, factionalism threatened purely democratic government. But see THE FEDERALIST No. 10, at 128 (James Madison) (Isaac Kramnick ed., 1987) ("Hence, it clearly appears that the same advantage which a republic has over a democracy in controlling the effect of faction is enjoyed by a large over a small republic-is enjoyed by the union over the states composing it.").

${ }^{77}$ See WEIHER, supra note 47 , at 179 ("[T] he proliferation of governments in the United States did not occur by divine fiat.").

${ }^{78}$ Frug, supra note 2, at 1076. 
within them." ${ }^{79}$ The tension in empowering local government is that such power is always at the will of the state, not at the will of the people as a romantic Jeffersonian view presumes. Where local government has been empowered, it has been by action of the state. ${ }^{80}$

However, we cannot simply rely on the notion that "[m] unicipal corporations are political subdivisions of the State, created as convenient agencies for exercising such of the governmental powers of the State as may be entrusted to them." ${ }^{81}$ Municipalities are more than governmental units. Local governments, by creating easily recognizable boundaries within a region, serve as proxies for socioeconomic status, race, lifestyle. They are no more mere subdivisions of the state than children are mere subdivisions of their parents. Admittedly, in both instances the superior being has the ability to force the inferior being to act against the inferior's wishes. The inferior being, however, still possesses its own identity independent of the superior being.

The law sometimes chooses to hang municipal power on this independent spirit of local governments. In areas where individuality is encouraged, local governments are empowered. These are the areas such as "home and family" and "community," is formulated. ${ }^{83}$ This identity, in turn, distinguishes one locale from

79 .

${ }^{80}$ For examples, see the New York and Pennsylvania home-rule statutes, N.Y. MUN. HOME RULE LAW $\$ 50$ (McKinney 1994); Act of Dec 19, 1996, ch. 29, 1996 Pa. Legis. Serv. 177 (West) (to be codified at 53 PA. CONS. STAT. ANN. \$ 2961) ("A municipality which has adopted a home rule charter may exercise any powers and perform any function not denied by the Constitution of Pennsylvania, by statute or by its home rule charter."). Although calling for grants of municipal power to be "liberally construed in favor of the municipality," such power is given by the state to local governmentnot taken by municipalities from the state. Id. Also, "local governments have no federal constitutional rights against their states and local residents have no constitutional claim to belong to particular local government." Voting Rights, supra note 3, at 792 n.90 (discussing Staten Island's obstacles to achieving secession).

${ }^{81}$ Hunter v. City of Pittsburgh, 207 U.S. 161, 178 (1907), overruled on other grounds by Baldwin v. Winston-Salem, 710 F.2d 132 (4th Cir. 1983).

${ }^{82}$ See Village of Belle Terre v. Boraas, 416 U.S. 1 (1974) (upholding a local ordinance restricting land use to single family dwellings); see also Frug, supra note 3, at 265 (discussing cases in which the Supreme Court has upheld local government authority to regulate community issues). Recently, the Eighth Circuit held that the City of St. Louis's interest in decreasing congestion and noise in residential areas was a rational basis for restricting single family dwellings to eight or fewer unrelated persons. See Oxford House-C v. City of St. Louis, 77 F.3d 249, 252 (8th Cir. 1996), cert. denied, 117 S. Ct. 65 (1996) ("Cities have a legitimate interest in decreasing congestion, traffic, and noise in residential areas, and ordinances restricting the number of unrelated people who may occupy a single family residence are reasonably related to these legitimate goals.").

${ }^{83}$ But see Williams, supra note 3, at 119 (citing the protection of property values, 
another, even though they are in the same state. "Political boundaries are manifestations of the widespread recognition of place, a spatial unit with its own identity, separate and recognizable from other spatial units." ${ }^{84}$

The independence of local government, however, is not unlimited. Local governments-themselves distinct political entities-coexist with other local governments in the region and the state. ${ }^{85}$ Furthermore, although the state law respects the independence of local government, it limits this independence when it conflicts with state goals. The tension between the independence of local government and state intrusions upon that independence parallels the tension between the independence of individuals and state intrusions upon individual autonomy. ${ }^{86}$

In order to gain a clearer understanding of the power of local governments we should compare instances in which the courts have upheld the independence of local government with those in which courts have disregarded local government boundaries. Polar definitions or concepts are of little value when attempting to find a practical, workable solution. To state that localism "lead[s] to an association of the locality with individual autonomy" ${ }^{87}$ does not determine at what point autonomy works for the good of all. Likewise, "Dillon's Rule," which states that local governments have only those powers that are specifi-

and not home and family, as the impetus for deference to local autonomy).

${ }^{84}$ WEIHER, supra note 47 , at 166 .

${ }^{85}$ The clearest judicial declarations on this theory are the Mount Laurel cases. See Southern Burlington County NAACP v. Township of Mount Laurel, 336 A.2d 713, 72728 (N.J. 1975) (Mount Laurel I) ("[T]he general welfare which developing municipalities... must consider extends beyond their boundaries and cannot be parochially confined to the claimed good of the particular municipality."); Southern Burlington County NAACP v. Township of Mount Laurel, 456 A.2d. 390, 422-35 (N.J. 1983) (Mount Laurel II) (instructing municipalities to coordinate development of low income housing projects to conform to a state plan); Hills Dev. Co. v. Township of Bernards, 510 A.2d 621, 632 (N.J. 1986) (Mount Laurel III) (upholding the constitutionality of the Fair Housing Act, N.J. STAT. ANN. §§ 52:27D-301 to -329 (West 1986 \& Supp. 1996), New Jersey's legislative response to the previous Mount Laurel which enables municipalities to determine "what is required [of] them").

${ }^{86}$ In essence, this is a privacy argument. See Roe v. Wade, 410 U.S. 113, 152 (1973) ("The Constitution does not explicitly mention any right of privacy. In a line of decisions ... the Court has recognized that a right of personal privacy, or a guarantee of certain areas or zones of privacy, does exist under the Constitution."); Griswold v. Connecticut, 381 U.S. 479, 483 (1965) (discussing different zones of privacy); see also Williams, supra note 3, at 85 (analyzing theories of local government law offered by Cooley, Dillon, Justice Brennan and the Burger Court majority, and finding a pattern: "each author's theory of city status is closely linked with his desire to rein in excessive governmental power" although each one sees different "nightmares of government run amok").

${ }^{87}$ Our Localism: Part II, supra note 3, at 444. 
cally granted by constitution or statute, or that arise by implication from an express grant of power, ${ }^{88}$ gives no guidance as to the breadth and depth of such power. By comparing instances of state power respecting local autonomy and individuality with examples of state power suppressing such individuality, we begin to cut a finer definition of the power of local governments and their place in political structure. ${ }^{8 y}$ I will examine three areas in which this tension has existed: 1) imposition of inter-local remedies, 2) manipulation of municipal boundaries, and 3) voting rights.

\section{A. Housing vs. Schools: Gautreaux, Milliken and Their Progeny}

Both housing and schools invoke notions of community spirit, home and family. If the power of local boundaries were centered solely on a Rockwellian ideal, then local boundaries would be respected in both areas. The state, however, has a clear interest in both housing and schools that could trample local boundaries in both instances. How, then, have the courts treated the existence of local boundaries in these two situations?

Hills v. Gautreaux ${ }^{90}$ and Milliken $v$. Bradley ${ }^{91}$ addressed the racial and economic externalities brought about by "white flight" from the city to the suburbs. In Gautreaux, black tenants and applicants for Chicago public housing claimed that the Chicago Housing Authority ("CHA") and the United States Department of Housing and Urban Development ("HUD") were guilty of racial discrimination in public housing. They sought a metropolitan-wide remedy to the discriminatory placement of public housing projects. ${ }^{92}$ In Milliken, parents of black school children in Detroit claimed that the Detroit public school system was racially segregated. They likewise sought a metropolitan-wide remedy

${ }^{88}$ SeeJOHN F. DILLON, 1 COMMENTARIES ON THE LAW OF MUNICIPAL CORPORATIONS 449, 448-451 (5th ed. 1911) ("[A] municipal corporation possesses and can exercise the following powers and no others: First, those granted in express words; second, those necessarily or fairly implied in or incident to the powers expressly granted; third, those essential to the accomplishment of the declared objects and purposes of the corporation-not simply convenient, but indispensable.").

${ }^{89}$ See Williams, supra note 3 , at 85 (noting that since cities "have no set place in American constitutional structure ... courts and commentators have been able to redefine city status without the textual constraints that limit reformulations of the status of the state and federal governments").
${ }^{90} 425$ U.S. 284 (1976).
9I 418 U.S. 717 (1974) (Milliken I).
92 See Gautreaux, 425 U.S. at 286-92. 
to open suburban schools to city children. ${ }^{93}$ In Gautreaux, the United States Supreme Court held that a metropolitan-wide remedy was appropriate. ${ }^{94}$ In Milliken, the Court ruled that such a remedy was inappropriate. ${ }^{95}$

The divergent remedies applied in these two cases are not grounded in whether local boundaries may be ignored when someone's constitutional rights have been infringed. Both cases clearly held that local boundaries "may be bridged where there has been a constitutional violation" and that such lines are "not sacrosanct and if they conflict with the Fourteenth Amendment federal courts have a duty to prescribe appropriate remedies." ${ }^{, 97}$ Rather, the difference lay in who committed the constitutional violation and to whom the remedy was addressed." $^{\text {"8 }}$

In the housing case, the defendants (HUD and CHA) created the racial discrimination. ${ }^{9 y}$ In response, the Court ordered HUD and CHA to disregard local boundaries. ${ }^{100}$ In the education case, the Court found no evidence that the suburban school district defendants had created the racial discrimination. ${ }^{101}$ As a result, the Court declined to approve a metropolitan-wide remedy "that would reach beyond the limits of the city of Detroit to correct a constitutional violation found to have occurred solely within that city."102

Note that even though the state of Michigan controlled the school districts, the Milliken Court rejected the reasoning of the Court of Ap-

${ }^{93}$ See Milliken I, 418 U.S. at 721-30.

${ }^{94}$ See Gautreaux, 425 U.S. at 305-06.

${ }^{95}$ See Milliken I, 418 U.S. at 752-53. However, the Supreme Court did uphold a lower court ruling implementing a city-based desegregation plan in Milliken v. Bradley, 433 U.S. 267, 291 (1976) (Milliken II).

${ }_{96}$ Milliken I, 418 U.S. at 741; see also Gautreaux, 425 U.S. at 300 (stating that local boundaries should not become "an arbitrary and mechanical shield for those found to have engaged in unconstitutional conduct").

${ }^{97}$ Miliken I, 418 U.S. at 744; see also Gautreaux, 425 U.S. at 298 ("Nothing in the Milliken decision suggests a per se rule that Federal courts lack authority to order parties found to have violated the Constitution to undertake remedial efforts beyond the municipal boundaries of the city where the violation occurred.").

68 "The critical distinction between HUD and the suburban school districts in Milliken is that HUD has been found to have violated the Constitution." Gautreaux, 425 U.S. at 297.

${ }^{99}$ See Gautreaux, 425 U.S. at 296 ("HUD does not dispute the Court of Appeals' determination that it violated the Fifth Amendment and $\S 601$ of the Civil Rights Act of $1964 \ldots . .$. ).

100 See id. at 298.

101 See Milliken I, 418 U.S. at 745.

${ }^{102}$ Id. at 757 (Stewart, J., concurring). 
peals that such control, coupled with de jure acts of discrimination by the state of Michigan, was enough to warrant implementation of a metropolitan-wide remedy. ${ }^{103}$ The Court required an interdistrict violation to justify an interdistrict remedy. As the Court stated in Gautreaux.

The District Court's desegregation order in Milliken was held to be an impermissible remedy not because it envisioned relief against a wrongdoer extending beyond the city in which the violation occurred but because it contemplated a judicial decree restructuring the operation of local governmental entities that were not implicated in any constitutional violation. ${ }^{104}$

This principle that discriminatory acts control the availability of a regional remedy remains the bright-line rule. Where school district boundaries are drawn for the purpose of "aiding and implementing" racial segregation, an interdistrict remedy may be imposed. ${ }^{105}$ In addition, courts will uphold voluntary desegregation agreements that cross school district boundaries. ${ }^{106}$ However, the constitutional violation will not be inferred; there must be proof of such violation. ${ }^{107}$ In its most recent ruling on this subject, the Supreme Court held that "white flight" does not rise to the level of a constitutional violation that will mandate

${ }^{103}$ See id. at 734-36 (describing the ruling of the court of appeals).

${ }^{104}$ Gautreaux, 425 U.S. at 296.

${ }^{105}$ Newburg Area Council, Inc. v. Board of Educ., 510 F.2d 1358, 1360 (6th Cir. 1974), cert. denied, 429 U.S. 1074 (1977); see also Evans v. Buchanan, 393 F. Supp. 428 , 432 (D. Del. 1975), aff'd, 423 U.S. 963 (1975) ("[T]o the extent that segregation imposed by state law has had inter-district effects, federal courts can fashion appropriate inter-district remedies.").

${ }^{106}$ See Liddell v. Missouri, 731 F.2d 1294, 1305 (8th Cir. 1984), cert. denied, 469 U.S. 816 (1984). The court was definite, however, as to the impact of a constitutional violation in its willingness to uphold the settlement agreement: "We make it clear, however, that no party found to have violated the Constitution will be permitted to escape its obligation to provide equal educational opportunity to the black children of St. Louis." Id. at 1297.

${ }^{107}$ "Proof of racially discriminatory intent or purpose is required to show a violation of the Equal Protection Clause." Village of Arlington Heights v. Metropolitan Hous. Dev. Corp., 429 U.S. 252, 265 (1977) (finding no "invidious purpose" behind denial of rezoning request to build low-income housing). The Court in Arlington Heights reaffirmed the position taken in Washington $v$. Davis that an action is not unconstitutional "solely because it results in racially disproportionate impact," Arlington Heights, 429 U.S. at 265, although proof of disproportionate impact can be used to prove invidious racial discrimination "because in various circumstances the discrimination is very difficult to explain on nonracial grounds." Washington v. Davis, 426 U.S. 229, 242 (1976). But see United States v. Board of Sch. Comm'rs, 637 F.2d 1101, 110608 (7th Cir. 1980), cert. denied, 449 U.S. 838 (1980) (holding that state's long history of racial discrimination was a significant factor in establishing discriminatory purpose). 
an interdistrict remedy. ${ }^{108}$

The distinctions made are clearer if we view local governments as extensions of the individual. As de Tocqueville noted: "the township, taken as a whole, and in relation to the central government is only an individual ...." The power of local government is no more and no less than the collective power of the individuals residing in that municipality. The recognition of local boundaries is premised upon the recognition of the rights of the individual. In Milliken $I$, the Court declined to grant a remedy that would force action by individuals (the suburban school districts) who had committed no constitutional violations. An individual who has not committed any wrong should not be made to remedy the wrongs of others. ${ }^{110}$ In contrast, in Gautreaux, the Court ordered the party who had committed the constitutional violation to remedy the violation. There was no requirement that nonviolating individuals (the suburban municipalities) take affirmative remedial steps. ${ }^{11}$

\section{B. Annexation and Other Manipulations of Municipal Boundaries}

The ability to reify or to mutate municipal boundaries upon the will of the people is the ultimate form of self-definition. Legal limitations on such change parallel legal limitations on the ability of the individual to define herself within both government and society. For example, annexation, with limited exceptions, can occur only with the consent of those residing in the area to be annexed. ${ }^{112}$ Just as one individual cannot force another into marriage, one municipality cannot force another into a merger without consent. The requirement of voluntary annexation is rooted in principles of self-determination and fundamental fair-

${ }^{108}$ Missouri v. Jenkins, 115 S. Ct. 2038, 2052 (1995). Even upon finding that a school districting scheme was unconstitutional, the Connecticut Supreme Court declined to impose an interjurisdictional remedy and instead deferred to the legislature. See Sheff v. O'Neill, 678 A.2d 1267, 1290-91 (Conn. 1996).

${ }_{109}^{10}$ DE TOCQUEVILLE, supra note 11 , at 58.

110 See Milliken v. Bradley, 418 U.S. 717, 745 (1974) (Milliken I) (“[W]ithout an interdistrict violation and interdistrict effect, there is no constitutional wrong calling for an interdistrict remedy.").

${ }^{11}$ See Hills v. Gautreaux, 425 U.S. 284, 298 (1976) ("Here, unlike the desegregation remedy found erroneous in Milliken, a judicial order directing relief beyond the boundary lines of Chicago will not necessarily entail coercion of uninvolved governmental units....").

${ }^{112}$ See Laurie Reynolds, Rethinking Municipal Annexation Powers, 24 URB. LAW. 247, 247 (1992). 
ness. $^{113}$

This power of self-determination, however, is only effective as against other municipalities. Beginning with Hunter $v$. City of Pittsburgh ${ }^{114}$ and moving forward, ${ }^{115}$ the state has had the power, at its pleasure, to "expand or contract the territorial area, unite the whole or a part of it with another municipality, repeal the charter and destroy the corporation." The municipality's rights as against those of other municipalities are coextensive with the rights that one individual has against another. A municipality's rights as against the state (or as against the federal government) extend only as far as an individual's rights against the state (or federal government). Like an individual who has no constitutional right to live in a particular local jurisdiction, ${ }^{117}$ a municipal government has no right to exist if the state decides otherwise. $^{118}$

Furthermore, just as private parties cannot contract to violate the fundamental rights of another, ${ }^{119}$ two municipalities cannot consolidate with impunity in a way that abridges an individual's fundamental rights. ${ }^{120}$ The clearest example of a violation of fundamental rights in

113 See id. at 248 (citing People ex rel Leland Grove v. Springfield, 520 N.E.2d 1205, 1209 (Ill. App. Ct. 1988) ("[F]undamental fairness dictates that the property owner must be allowed to choose between the several municipalities vested with annexation jurisdiction....")).

114207 U.S. 161 (1907).

115 See, e.g., Holt Civic Club v. City of Tuscaloosa, 439 U.S. 60, 71 (1978) ("While the broad statements as to state control have undoubtedly been qualified ... we think that [Hunter] continues to have substantial constitutional significance in emphasizing the extraordinarily wide latitude that States have in creating various types of political subdivisions and conferring authority upon them."); Township of Jefferson v. City of West Carrollton, 517 F. Supp. 417, 419 (S.D. Ohio 1981), aff d, 718 F.2d 1099 (6th Cir. 1983) (table) ("Hunter... still reflects the viable principle of law that annexation matters fall entirely within the discretion and standards of the state constitution ....").

${ }_{116}$ Hunter, 207 U.S. at 178-79.

117 See id. at 179 (noting that a state may modify a municipality in any way, "unrestrained by any provision of the Constitution of the United States").

${ }^{118}$ Furthermore, there is no absolute right under the Due Process Clause to vote on proposed alterations to municipal boundaries. See id., 207 U.S. at 179 (stating that alterations may be made "conditionally or unconditionally, with or without the consent of the citizens, or even against their protest"); Adams v. City of Colorado Springs, 308 F. Supp. 1397, 1400 n.3 (D. Colo. 1970), aff'd, 399 U.S. 901 (1970) ("The state therefore, at its pleasure, may... expand or contract the territorial area, unite the whole or a part of it .... with or without the consent of the citizens ...."), affd mem., 399 U.S. 901 (1970).

${ }^{119}$ See discussion infra Part III.

${ }^{120}$ See Gomillion v. Lightfoot, 364 U.S. 339, 345 (1960) (holding that the Fifteenth Amendment prevents a state from manipulating political subdivisions so as to defeat the federally protected right to vote); City of Port Arthur v. United States, 459 U.S. 159 
this context is dilution of voting power. ${ }^{121}$ Although not all expansions of municipal borders that dilute the voting power of particular groups are prohibited, such dilution must be addressed and ameliorated. ${ }^{122}$ To summarize, the rights of the municipality as against the state and federal government extend no further than the rights of the individual as against the government.

In the same vein, a municipality cannot secede if such a secession abridges a citizen's fundamental rights. For example, courts have consistently blocked racially motivated secession attempts that were undertaken in response to court-enforced school desegregation efforts. ${ }^{123}$ More recently, the federal judiciary has reiterated its willingness to strike down a secession bid even if a facially neutral reason is given for the secession: "the doors to Federal court will be wide open should the political process ultimately work an unconstitutionally discriminatory result."

(1982) (Powell, J., dissenting) (noting that annexation that abridges the fundamental right to vote is only permitted if the municipal voting scheme is realigned to counteract such voter dilution); City of Richmond v. United States, 422 U.S. 358, 370-71 (1975) (stating that a municipality created by annexation must "fairly reflect[] the [voting] strength of the [minority] community").

${ }_{121}$ See Reynolds v. Sims, 377 U.S. 533, 555 (1964) (“[T]he right of suffrage can be denied by a debasement or dilution of the weight of a citizen's vote just as effectively as by wholly prohibiting the free exercise of the franchise.").

${ }_{22}$ See, e.g., City of Petersburg v. United States, 354 F. Supp. 1021, 1031 (D.D.C. 1972), aff'd mem., 410 U.S. 962 (1973) (“[Annexations are] approved only on the condition that modifications [in the electoral plan] calculated to neutralize to the extent possible any adverse effect upon the political participation of black voters are adopted ...."); City of Richmond v. United States, 422 U.S. 358, 370 (1975) (expressly reaffirming City of Petersburg).

${ }_{123}$ See, e.g., United States v. Scotland Neck City Bd. of Educ., 407 U.S. 484 (1972); Wright v. Council of Emporia, 407 U.S. 451, 460 (1972) ("If the proposal [to create a new district] would impede the dismantling of the dual system, then a district court, in the exercise of its remedial discretion, may enjoin it from being carried out."); Burleson v. County Bd. of Election Comm'rs, 308 F. Supp. 352, 357 (E.D. Ark. 1970) (noting that there may be times where secession from a school district raises no constitutional objection if "one or more parts will not have a substantial Negro population and thus will have no integration problem"), aff'd mem., 432 F.2d 1356 (8th Cir. 1970) (per curiam).

Jones v. Deutsch, 715 F. Supp. 1237, 1240 (S.D.N.Y. 1989). In Jones the municipality denied a secession petition because boundary lines were drawn in a racially discriminatory manner. Although the federal court did not reach the merits due to procedural defects, it issued an open invitation to adjudicate if the procedural defects were cured.

This "open door" policy is not limited to cases involving constitutional violations. The disparate impact analysis of Title VI litigation was employed by a federal court in a Fair Housing Act case to strike down a zoning regulation prohibiting the construction of subsidized housing in a white neighborhood. See Huntington Branch NAACP v. Town of Huntington, 844 F.2d 926, 934 (2d Cir. 1988) (“[T]he disparate impact ap- 
ther than that of the individual.

\section{Local Governments and Voting Rights}

The law also limits local government self-determination in the context of disproportionate voting schemes. A local jurisdiction has no "right" to function as a voting district. The existence of a local boundary will be disregarded if recognition will result in dilution of voting power. $^{125}$ Furthermore, the Equal Protection Clause requires population equality between voting districts even in local government elections. ${ }^{126}$ If population deviation between districts is too high then "historic respect for the integrity of [local] boundaries" falls. ${ }^{127}$

While noting that valid considerations may underlie the "desire to maintain the integrity of various political subdivisions" (such as municipal and county boundaries), ${ }^{128}$ the Supreme Court has held that political subdivisions of the state are not sovereign entities. ${ }^{129}$ Therefore, the overriding objective in state legislative apportionment "must be substantial equality of population among the various districts, so that the vote of any citizen is approximately equal in weight to that of any other citizen." While "[m]athematical exactness or precision is hardly a workable constitutional requirement," "131 "deviations from population equality must be justified by legitimate state considera-

proach of Title VII cases is fully applicable to this Title VII case brought against a public defendant."), affd, 488 U.S. 15 (1988) (per curiam).

Title VII's scope is, by definition, statutory and, thus, perhaps not as illustrative as constitutional limitations on the power of local government. Cases such as Huntington, however, show a clear direction of the judiciary to hold local government responsible for discriminatory actions just as it would an individual.

${ }_{125}$ See supra notes 121-22 and accompanying text.

${ }^{126}$ See Abate v. Mundt, 403 U.S. 182, 185 (1971) ("It is well established that electoral apportionment must be based on the general principle of population equality and that this principle applies to state and local elections."); Avery v. Midland County, 390 U.S. 474, 481 (1968) ("We therefore see little difference, in terms of the application of the Equal Protection Clause ... between the exercise of state power through legislatures and its exercise by elected officials in the cities, towns, and counties.").

${ }_{127}$ Connor v. Finch, 431 U.S. 407,416 (1977) (holding that a deviation of $16.5 \%$ from population equality was unacceptable).

${ }_{128}$ Reynolds v. Sims, 377 U.S. 533, 578 (1964); see also Abate, 403 U.S. at 185 ("[O] ur statements have reflected the view that the particular circumstances and needs of a local community as a whole may sometimes justify departures from strict equality.").

\footnotetext{
${ }_{199}$ See Reynolds, 377 U.S. at 575.

130 Id. at 579 .

131 Id. at 577.
} 
tions. ${ }^{\text {"192 }}$ Hence, local government boundaries can dissolve in the face of a constitutional challenge. ${ }^{139}$

As discussed above, the creation of a fractured system of local government allows citizens an extension of self. This confluence of the individual with the community likewise empowers local government: the legal position of these governments is grounded in the legal position of the individual. If we juxtapose these seemingly inconsistent sources of local government power, we find at the core one central theory. The true legal power of local government (unlike state and federal government) is premised upon the notion that its citizens form one collective individual. If the law treats local government as a "collective individual," is it any surprise that consumers search for that collective individual who looks, thinks and acts as they do? The collective individual not only composes the economic, political and social bases of local government power, but also creates its legal power.

\section{THE COLLECTIVE INDIVIDUAL AND MORAL HYPERNORMS}

I do not want Negroes in the City of Parma.

- Kenneth Kuczma, President of the Parma City Council in $1971^{194}$

192 Abate, 403 U.S. at 185; see also Board of Estimate v. Morris, 489 U.S. 688, 701-03 (1989) (striking down New York City Board of Estimate apportionment scheme of one borough, one vote). But see Brown v. Thomson, 462 U.S. 835, 847-48 (1983) (upholding an admittedly disproportionate county-based apportionment scheme due to Wyoming's constitutional policy of preserving county boundaries and the absence of any hint of arbitrariness or discrimination).

At-large voting systems are also subject to attack if a racially discriminatory purpose is proven. See Rogers v. Lodge, 458 U.S. 613, 621-22 (1982) (holding that at-large voting systems must be upheld against constitutional attack unless they are maintained for a discriminatory purpose); City of Mobile v. Bolden, 446 U.S. 55, 66-67 (1980) (same).

${ }^{133}$ Contrast this with the constitutionally created power of state boundaries in federal voting. States with disparate populations retain their ability to vote as a state. See U.S. CONST. art. I, § 3. Not only is this established in the creation of the United States Senate (two senators per state, regardless of population), but is also evident in national election law. The Electoral College, which elects the President, gives three votes to the state of Wyoming, which had 480,000 inhabitants in 1995. Montana also gets three votes with almost twice as many residents $(870,000)$. See U.S. DEP'T COMMERCE, STATISTICAL ABSTRACT OF THE U.S. tbls. 27, 434 (1996).

${ }^{194}$ Government's Exhibit 118, United States v. City of Parma, 494 F. Supp. 1049, 1065 (N.D. Ohio 1980), aff'd, 661 F.2d 562 (6th Cir. 1981) (holding that Parma, by rejecting low-income housing and enacting ordinances precluding construction of lowincome housing, violated the Fair Housing Act). Parma is Cleveland's largest suburb. In the 1970s Parma had a reputation as a white, ethnic, suburban enclave. In 1973 the U.S. Justice Department sued the City of Parma, alleging that the city had violated the Fair Housing Act. President Kuczma's remarks were made during a meeting in which 
Having made the case for recasting local government to collections of individuals, I am uneasy about the whole proposition. Is it sound to permit unfettered "balkanization" of local government to go unchecked by any moral limitations? Taken to its logical end, the elevation of individual preference to the point of political and legal power would permit unchecked discrimination on any basis, with the justification that it was the collective will of the new community. Clearly there must be some limit on the individual/collective will. The difficulty in formulating this limitation is that the homogeneity prevalent in local government limits dissent and the ensuing discourse that would otherwise challenge moral decisions. ${ }^{135}$ How, then, do we externally impose moral limitations while maintaining internal freedom of will? The solution to this dilemma calls for a balancing act. On one side of the scale is the necessity to uphold certain normative limitations imposed by society outside of the community. On the other side is the necessity for a community to exclude in order to achieve the goal of "local government."

\section{A. The Legal Ability to Exclude}

Exclusion is the antithesis of the popular notion of the principles for which our country stands. Exclusion, however, defines who we are. Whether such exclusion is on a national level, as in immigration limitations, ${ }^{136}$ or on a local level, as in segregated residential patterns, ${ }^{137}$ we

a proposed subsidized housing project was rejected. This rejection formed part of the Justice Department's case against Parma. The district court imposed a remedial order designed to promote residential racial integration in Parma. See United States v. City of Parma, 504 F. Supp. 913, 918-23 (N.D. Ohio 1980), aff'd in part, rev'd in part, 661 F.2d 562 (6th Cir. 1981) (enjoining the City of Parma from actions that violate the Fair Housing Act and ordering the city to implement fair housing education programs, to enact a fair housing resolution, to advertise Parma as an open community, and to take actions to increase the supply of low-income housing). The mayor and leaders of city council resisted the remedial order, delaying its implementation until 1983. Although some progress has been made (the 1990 census showed a black population of $0.75 \%$ as compared to $0.04 \%$ in 1970), see W. DENNIS KEATING, THE SUBURBAN RACIAL DILEMMA 3 (1994), such progress has been slow and Parma's image as a racist community remains. For further discussion of Parma and other situations facing African Americans in the suburbs, see $i d$. (addressing "housing segregation and efforts at housing integration in the suburbs of metropolitan areas").

${ }^{135}$ As Professor Ford notes, "individualism comes with a covert normative structure... [that] makes it difficult to understand the political claims of minority, racial and cultural groups as anything other than strategic, distributive, remedial or separatist." Ford, supra note 3, at 1892 n.149.

${ }^{136}$ For example, The Quota Act of 1921, ch. 8, 42 Stat. 5, and the Immigration Act of 1924, ch. 190, 43 Stat. 153, limited immigrant admission contingent upon the national origin of the immigrant. Under these acts the number of immigrants from any one nation was limited to $3 \%$ of the number of foreign-born persons of such national- 
cannot close our eyes to the existence of legally sanctioned exclusion. Such exclusion, though, should not be viewed as democratic deficiency, but rather as "a necessary consequence of a community's process of selfdefinition." "138

An all-inclusive community is oxymoronic. ${ }^{139}$ Such an all-inclusive community would be a community without parameters, boundaries or definition. It would not be a community. Community is based on commonality, and commonality is the antonym of difference. Exclusion, for all of its negative connotations to our liberal-thinking minds, is necessary for the creation of self. After all, we are not only defined by what we are but also by what we are not. The difficulty in addressing exclusion based on difference is that ascribing difference is not a valueneutral exercise. As Professor Minow points out: "The attribution of difference hides the power of those who classify and of the institutional arrangements that enshrine one type of person as the norm, and then treat classifications of difference as inherent and natural while debasing those defined as different."140

ity resident in the United States as determined by the Census of 1910 . See Andrew Smith, The Rough Road for Vietnamese Visa Applicants in Hong Kong, 21 N.C. J. INT'L L. \& COM. REG. 649, 656 \& n.74 (1996) (providing a background for United States immigration legislation); see also Frank H. Wu, The Limits of Borders: A Moderate Proposal for Immigration Reform, 7 STAN. L. \& POL'Y REV., Summer 1996, at 35, 42 (discussing how prior to 1965 immigration by Eastern and Southern Europeans was limited by strict quotas, especially if their countries of origin were more heavily Catholic or Jewish).

${ }^{137}$ African Americans in the United States experience "hypersegregation" to a greater degree than any other minority group, especially when analyzing neighborhood dissimilarity (ethnic concentration) and spatial isolation (clustering of racially concentrated neighborhoods). See Douglas S. Massey \& Nancy A. Denton, Hypersegregation in U.S. Metropolitan Areas: Black and Hispanic Segregation Along Five Dimensions, DEMOGRAPHY, Aug. 1989, at 373, 389 ("Blacks are thus unique in experiencing multidimensional hypersegregation."). See generally THE HOUSING STATUS OF BLACK AMERICANS (Wilhelmina Leigh \& James Stewart eds., 1992) (exploring the limited housing opportunities available to blacks caused by continued racial discrimination and economic and policy changes). Furthermore, African Americans experience suburban segregation at higher levels than any other U.S. minority group. See Thomas J. Phelan \& Mark Schneider, Race, Ethnicity, and Class in American Suburbs, 31 URB. AFF. REV. 659, 675 (1996) ("Despite substantial changes over time in the ethnic composition of migrants to suburbs, blacks are still the most highly underrepresented ethnic group of the "big three' minority ethnic groups in the United States.").

${ }^{158}$ Cabell v. Chavez-Salido, 454 U.S. 432, 439 (1982) (holding that strict scrutiny is inappropriate where the restriction against aliens "primarily serves a political function").

${ }^{139}$ "A 'difference community' is an oxymoron." James W. Torke, What Price Belonging: An Essay on Groups, Community, and the Constitution, 24 IND. L. REV. 1, 33 (1990) (defining a "difference community" as a community that emphasizes differing views and beliefs as opposed to sameness).

${ }^{140}$ Martha Minow, Making All the Difference: INCLUSION, EXCLUSION AND 
The goal, then, is to identify universal norms for regulating exclusion based on difference. Such "hypernorms" of the collective community. ${ }^{142}$ Such universally imposed norms are necessitated, not only by obligations of societal morality, but also by every day reality. As communities are in close proximity, if not contiguous with each other, there will undoubtedly be substantial intercommunity relationships. If for no other reason than efficiency, ${ }^{143}$ overriding norms that apply regardless of geographic location must be established. ${ }^{144}$ Think of the region expressed as a series of concentric circles with an individual in the center and the entire region as the outermost ring. As we move out along the radius, we can expect to find less and less consensus as to norms because consensus falls as there is more diversity of opinion. However, strong norms will emerge; these are our hypernorms. The discovery of these hypernorms will enable us to determine, hypothetically, when and on what basis exclusion for difference is permitted and when it is prohibited. In essence the hypernorm will establish the line between decisions that are private and beyond the scope of governmental intervention and those that are not. ${ }^{145}$

AMERICAN LAW 111 (1990).

${ }^{141}$ See Thomas Donaldson \& Thomas W. Dunfee, Toward a Unified Conception of Business Ethics: Integrative Social Contracts Theory, 19 ACAD. MGMT. REV. 252, 265 (1994) ("Hypernorms... entail principles so fundamental to human existence that they serve as a guide in evaluating lower level moral norms. As such, we would expect them to be reflected in a convergence of religious, philosophical and cultural beliefs ....").

${ }^{142}$ To explain how hypernorms will overrule even the unanimous consent of parties to microsocial contracts, Dunfee and Donaldson use the example that contractors would not permit microsocial contracts that condone murder as a method of enforcing contracts even under conditions of unanimous consent because a rule against murder is included in a set of standards to which all societies can be held. See id. at 265.

${ }^{143}$ For example, enforcement of racially restrictive covenants in one community but not another would result in real estate agents and apartment managers analyzing the family tree of all prospective buyers and renters, thereby resulting in additional transaction costs.

${ }^{144}$ The logical question at this point is whether these norms should merely be suggestions, with the market determining compliance, or whether these norms should have the force of law and be actionable. This same discussion is played out today in discussions on affirmative action. The difficulty in relying on the market model to assure compliance is that discrimination (i.e., exclusion) is sometimes perfectly rational and the market will not punish a rational actor. The interventionist model, which legally punishes noncompliance, is the only way to assure the even application of hypernorms across community lines. For a discussion of the interventionist model versus the market model to eradicate housing discrimination and segregation, see Alex $M$. Johnson, Jr., How Race and Poverty Intersect to Prevent Integration: Destabilizing Race as a Vehicle to Integrate Neighborhoods, 143 U. PA. L. REV. 1595, 1616 (1995).

${ }^{145}$ There is a consensus amongst anthropologists, political scientists and philosophers that there exists such a convergence of beliefs across cultures that identifies hyper- 


\section{B. Limitations on the Ability to Exclude}

This country has had a long history of racial discrimination. ${ }^{146}$ As a society though, we have moved (albeit in fits and starts) away from the institutionalized racism of slavery, through state imposed racism of the Jim Crow era, through tolerance of racism in spheres not implicating fundamental rights, and finally, to attempts at erasing racism altogether through programs such as affirmative action and preferential treatment. By analyzing the role of the law in housing discrimination, a small aspect of the multifaceted problem of racial discrimination, we can begin to devise when individual decisions to discriminate must succumb to externally imposed norms of multicultural inclusion. Housing discrimination cases are well suited to this endeavor because of the courts' willingness to impose state values on private decisions. ${ }^{147}$

\section{Necessity of State Action}

Beginning with Buchanan v. Warley, ${ }^{148}$ the Supreme Court has refused to allow the state to be an active participant in private housing discrimination. In Buchanan, the Court struck down a city provision

norms. See Donaldson \& Dunfee, supra note 141, at 265-66.

${ }^{146}$ I speak here not solely of de jure discrimination resulting in racial segregation, discussed infra, but also of de facto racial segregation that still persists today. See generally DOUGLAS S. MASSEY \& NANCY A. DENTON, AMERICAN APARTHEID: SEGREGATION AND THE MAKING OF THE UNDERCLASS 84 (1993) ("Although the racial climate of the United States improved outwardly during the 1970s, racism still restricted the residential freedom of black Americans; it just did so in less blatant ways."); Douglas S. Massey \& Nancy A. Denton, Patterns of Neighborhood Transition in a Multiethnic World: U.S. Metropolitan Areas, 1970-1980, 28 DEMOGRAPHY 41 (1991) (concluding that "white population loss is related strongly to both the proportion of minority members and the distance to established minority neighborhoods; this relationship builds a self-feeding dynamic into the process of ghetto expansion"); Massey \& Denton, Hypersegregation, supra note 137, at 388 (confirming previous studies documenting a persistently high degree of black residential segregation and suggesting that this segregation is "even more extreme than previously imagined"); see also Richard H. Sander, Comment, Individual Rights and Demographic Realities: The Problem of Fair Housing, 82 Nw. U. L. REV. 874,87476 (1988) (exploring why fair housing laws have failed to bring about housing integration).

${ }^{47}$ A discussion of how the public/private dichotomy factors into the Court's willingness to intervene is not novel. See, e.g., Barbara Rook Snyder, Private Motivation, State Action and the Allocation of Responsibility for Fourteenth Amendment Violations, 75 CORNELI L. REV. 1053, 1053 n.I (1990) (providing a partial list of scholarship concerning the state action requirement). What I hope to accomplish here is to present a brief analysis of the changing and evolving scope of this distinction that will highlight the power of societal interest over private agreements.

245 U.S. 60 (1917). 
that permitted discrimination on the basis of race in the sale or lease of houses. ${ }^{149}$ Relying on its decision in Buchanan, the Court ten years later, had no difficulty declaring a racially discriminatory town ordinance invalid in the 1927 case of Harmon v. Tyler. ${ }^{150}$ Yet, just one year earlier, in 1926 , the Court was unwilling to strike down a racially restrictive covenant in Corrigan v. Buckley ${ }^{151}$ because the restrictive covenant at issue was a private contract with no state involvement. The Court dismissed the action for lack of jurisdiction because, inter alia, it found no constitutional prohibition on "private individuals ... entering into contracts respecting the control and disposition of their own property."152

In 1948, in Hurd v. Hodge $e^{153}$ and Shelley $v$. Kraemer, ${ }^{154}$ the issue at hand was once again a private agreement-a restrictive covenant. The restrictive covenant ran with the land and prohibited sale of the property to non-Caucasians. The petitioners sought an injunction to enforce the covenant.

The imposition of state action was not nearly as direct in these cases as it had been in Buchanan. Instead of the state promulgating a racial restriction, as was the case in Buchanan, in these cases the argument was that the state was using its power to enforce a privately imposed racial restriction. However, despite the less direct state action, in each case the court found this state action of enforcement unconstitutional. ${ }^{155}$ The court carefully avoided declaring the covenants invalid. ${ }^{156}$ In both

${ }^{149}$ The Court explained:

We think this attempt to prevent the alienation of the property in question to a person of color was not a legitimate exercise of the police power of the State, and is in direct violation of the fundamental law enacted in the Fourteenth Amendment of the Constitution preventing state interference with property rights except by due process of law.

Id. at 82.

${ }_{150} 273$ U.S. 668 (1927) (per curiam). Ordinance No. 8037, C. C. S., adopted by the City of New Orleans on September 18, 1924, forbade African Americans from occupying houses in a white community or whites from occupying houses in African American communities except upon written consent of a majority of persons of "opposite" race in the community affected.

271 U.S. 323 (1926).

${ }^{152}$ Id. at 330 .

153334 U.S. 24 (1948).

154334 U.S. 1 (1948).

${ }^{153}$ See id. at 20; Hurd, 334 U.S. at 35.

156 "So long as the purposes of those agreements are effectuated by voluntary adherence to their terms, it would appear clear that there has been no action by the State and the provisions of the [Fourteenth] Amendment have not been violated." Shelley, 334 U.S. at 13.

Nothing in the opinion of this Court ... may properly be regarded as an adjudication of the issue presented by petitioners in this case which concerns, 
Hurd and Shelley, the Court was determining the validity of the enforcement of the covenants, not the validity of the covenants themselves.

We see the beginning of the discovery of our hypernorm: at the threshold, discriminatory private agreements are subject to state intervention if there is state action involved to enforce such agreements.

\section{Abandoning the State Action Requirement}

Building on Shelley, the Court in Barrows v. Jackson, ${ }^{157}$ again invalidated the enforcement of a private covenant based on state action. Unlike Shelley, the state in Barrows was not asked to "enforce" a racially restrictive covenant through the court's equity powers. Rather, the question presented was whether there was state action in the awarding of damages in a civil suit for breach of contract for violating the restrictive covenant. The Court shifted away from reliance on direct state action and held that "[i]f the State may thus punish respondent for her failure to carry out her covenant, she is coerced to continue to use her property in a discriminatory manner.... [Such punishment] would constitute state action as surely as it was state action to enforce such covenants in equity ...."158

Chief Justice Vinson, who wrote the Court's decisions in Shelley and Hurd, dissented and sought to limit the voiding of such covenants to in-

not the validity of the restrictive agreements standing alone, but the validity of court enforcement of the restrictive covenants under the [D]ue [P] rocess [C]lause of the Fifth Amendment.

Hurd, 334 U.S. at $28-29$.

${ }^{157} 346$ U.S. 249 (1953).

${ }^{158}$ Id. at 254 (citing Shelley, 334 U.S. 1). The Court in this case also broadened the status of potential litigants in housing discrimination cases. Eschewing the threshold requirement that the party show that he or she is in the class whose constitutional rights are allegedly infringed (the petitioner here being a home seller, not a prospective minority purchaser), the Court stated:

[W] are faced with a unique situation in which it is the action of the state court which might result in a denial of constitutional rights and in which it would be difficult if not impossible for the persons whose rights are asserted to present their grievance before any court. Under the peculiar circumstances of this case, we believe the reasons which underlie our rule denying standing to raise another's rights.... are outweighed by the need to protect the fundamental rights which would be denied by permitting the damages action to be maintained.

Barrows, 346 U.S. at 257 . This dilution of the standing requirement may be interpreted to indicate the Court's willingness, at times, to use extraordinary means to address and manipulate private agreements that contravene the public goal of the eradication of housing discrimination. 
stances where there was direct state action against a member of a protected class. Pertinent to our discussion of state intervention in private agreements, the Chief Justice wrote:

[T] hese racial restrictive covenants... are not legal nullities so far as any doctrine of federal law is concerned; it is not unlawful to make them; it is not unlawful to enforce them unless the method by which they are enforced in some way contravenes the Federal Constitution or a federal statute. ${ }^{159}$

A brief pause here at the crossroads of Barrows allows us to mull over the limitations of state regulation of private agreement. The Court has unanimously struck down instances where the state perpetuates (Buchanan, Harmon) or facilitates (Hurd, Shelley) racial discrimination. Historically, though, the Court has shied away from striking down "purely private" contracts (Corrigan). By recognizing that a more diffuse standard, the murky notion of "coercion," violates the rights of unspecified third parties-moving away from the bright line rule of state enforcement-the Court has signaled its willingness to sacrifice the private agreement for the public good.

The Court, however, is still struggling with the notion brought forth in the Civil Rights Cases. ${ }^{160}$ Action prohibited by the Fourteenth Amendment "is only such action as may fairly be said to be that of the States. That Amendment erects no shield against merely private conduct, however discriminatory or wrongful."161 Yet the Court finds housing discrimination so repugnant that in this "unique set of circumstances" ${ }^{\prime 162}$ it has begun to relax both procedural (standing questions) and substantive (state action) requirements.

We can begin to tease out our hypernorm: private action that results in racial/ethnic discrimination presents such a "unique" situation that it cannot be aided by the state even if there is no direct state involvement. While it may not be unlawful to be a bigot, the state will not assist you in such endeavors. What is undecided is the scope of the definition of "aid." The Court is moving away, notwithstanding dissent, from the idea that "aid" is confined to state action, as characterized by active enforcement, and moving towards the notion that "aid" includes any state involvement.

Running parallel with the Court's exploration of the evolving con-

${ }^{159}$ Barrows, 346 U.S. at 261 (Vinson, C.J., dissenting).

160109 U.S. 3 (1883).

161 Shelley, 334 U.S. at 13.

162 Barrows, 346 U.S. at 259. "The Court, by a unique species of arguments, has developed a unique exception to an otherwise easily understood doctrine." Id. at 260-61 (Vinson, C.J., dissenting). 
stitutional role of the state in regard to private, discriminatory contracts, are the legislative initiatives that reflect a growing public dissatisfaction with racially restrictive covenants. Passed as a part of the Civil Rights Act of 1866, 42 U.S.C. $\$ 1982$ provides that the purchase, sale or leasing of real and personal property is afforded to all citizens of the United States without regard to color. ${ }^{163}$ This law was originally held to apply only to state action. ${ }^{164}$ However, in 1968, in Jones v. Alfred H. Mayer Co. ${ }^{1155}$ the Supreme Court took the "state action" requirement out of the equation. The Court reversed the decision of the court of appeals, which had held that $\S 1982$ only applied to state action and thus did not reach private refusals to sell real property based on race. Therefore, after Jones, intervention is no longer relegated to the shadows. The Court embraced state intervention in private agreements even in the absence of state action. "We hold that $\$ 1982$ bars all racial discrimination, private as well as public, in the sale or rental of property, and that the statute, thus construed, is a valid exercise of the power of Congress to enforce the Thirteenth Amendment."

It is worth noting that the Court's decision in Jones is not predicated on the Fair Housing Title (Title VIII) of the Civil Rights Act of $1968 .^{167}$ Title VIII is full of proscriptions, ${ }^{169}$ prescriptions, ${ }^{169}$ causes of action ${ }^{170}$ and remedies. ${ }^{171}$ By contrast, $\S 1982$ is a single flat pronouncement that requires the courts, through judicial interpretation, to find the level at which a citizen's rights to real property have been abridged on account of race. The Court's explicit reliance on $\S 1982$ provides us with an even stronger normative compass than reliance upon Title VIII would

${ }^{163}$ "All citizens of the United States shall have the same right, in every State and Territory, as is enjoyed by white citizens thereof to inherit, purchase, lease, sell, hold, and convey real and personal property.” 42 U.S.C. § 1982 (1996).

I6t Jones v. Alfred H. Mayer Co., 379 F.2d 33, 4445 (8th Cir. 1967). Hurd v. Hodge, 334 U.S. 24, 34 (1948), was also decided upon analysis of $\S 1982$, but there the Court found sufficient state action to apply the statute.

165392 U.S. 409 (1968).

${ }^{360}$ Id. at 413.

${ }^{167}$ Pub. L. No. 90-284, 82 Stat. 81 (codified as amended at 42 U.S.C. $\$ 3601$ (1996)) (making discrimination in housing rentals and sales illegal); Jones, 392 U.S. at 413.

${ }^{j 68} \$ 804$ (a)-(e), 82 Stat. at 83 (prohibiting discrimination in the sale or rental of housing).

${ }^{169} \$ 808$ (e), 82 Stat. at 85 (describing the duties of the Secretary of Housing and Urban Development).

${ }_{170} \S \S 810-813,82$ Stat. at $85-88$ (listing causes of action that trigger Title VII). court.).

$171 \$ 812,82$ Stat. at 88 (granting remedies for Title VIII violations in federal 
have. ${ }^{172}$ The wide latitude of discretion afforded the Court in actions based upon $\S 1982$ allows the Court to fashion its decision not upon statutory limitations but rather upon prevailing societal norms.

One year later in Sullivan v. Little Hunting Park, Inc., ${ }^{179}$ the Court revisited the application of $\S 1982$ to private contracts and expanded its holding in Jones. In Sullivan, an African-American resident was denied membership to a community pool and park, although he held a membership share. ${ }^{174}$ The issue before the Court was whether the refusal to grant membership to African Americans solely on the basis of race denied them property rights in violation of $\S 1982$. Based upon its decision in Jones, the Court held that $\$ 1982$ was applicable to private agreements and that the membership share in the park was property as covered by $\S 1982 . .^{175}$

Justice Harlan dissented again in Sullivan, objecting once again to the crossing of the public/private line of demarcation. ${ }^{176}$ There was another disagreement; Harlan raised the question of why the Court was deciding this case when the Fair Housing Act would have been better suited to the task. ${ }^{177}$ Harlan cautioned against the use of $\S 1982$ to

172 The Court's expansion of the applicability of $\S 1982$, however, was not unanimous. Justice Harlan's dissent in Jones reiterates the same concerns raised by Chief Justice Vinson in Barrozus. Justice Harlan argued, "the Court's construction of $\$ 1982$ as applying to purely private action is almost surely wrong, and at the least is open to serious doubt." Jones, 392 U.S. at 450 (Harlan, J., dissenting).

173396 U.S. 229 (1969).

174 See id. at 234-35. The African-American resident who was denied use of the facilities had been assigned a membership share in connection with his lease of a house in the area. According to the bylaws of Little Hunting Park, Inc.-the nonstock corporation organized to operate the community's recreational facilities-a person who rented his home and who owned a membership share was entitled to assign that membership share to the tenant. A membership share entitled its holder to use the community recreational facilities. Id.

${ }^{175}$ See id. at 236 ("What we have here is a device functionally comparable to a racially restrictive covenant, the judicial enforcement of which was struck down in Shelley $v$. Kraemer....").

${ }^{176}$ See id. at 247, 248 (Harlan, J., dissenting) ("Today the Court goes yet beyond Jones...."). Justice Harlan's public/private distinction, however, does have its limits. In his concurrence in Bivens v. Six Unknown Named Agents of the Federal Bureau of Narcotics, he noted that "injuries inflicted by officials acting under color of law ... are substantially different in kind [from those inflicted by private parties]." Bivens v. Six Unknown Named Agents of the Federal Bureau of Narcotics, 403 U.S. 388, 409 (1971) (Harlan, J., concurring) (asserting that statutory authority is not necessarily a prerequisite to constitutional enforcement in damage suits).

${ }^{177}$ See Sullivan, 396 U.S. at 241-42 (Harlan, J., dissenting). Justice Harlan argued:

Because the Fair Housing Law will become fully effective less than three weeks from now, I think the majority even more unwise than it was in Jones, in precipitately breathing still more life into $\S 1982$, which is both vague and 
combat racial discrimination in housing because "lurking in the background are grave constitutional issues should $\S 1982$ be extended too far into some types of private discrimination. [Section] 1982 fail[s] to provide standards as to the types of transactions in which discrimination is unlawful ....."178

The essence of the public/private distinction crystallizes. Why would the Court stretch to reformulate private transactions based on $\S 1982$ when a cause of action in the Fair Housing Act was waiting in the wings? The exigency and importance of civil rights and the eradication of housing discrimination based on race was such a normative imperative that it required extraordinary measures. ${ }^{179}$ Our hypernorm can be refined: racial and ethnic discrimination will not be tolerated by the govermment. Moreover, the government is empowered to void purely private transactions that contravene this goal. ${ }^{180}$

open-ended, when Congress has provided this modern statute, containing detailed remedial provisions aimed at eliminating racial discrimination in housing.

Id. (footnote omitted).

${ }^{178}$ Id. at 248 (citing The Civil Rights Cases, 109 U.S. 3 (1883)); see also supra note 172 and accompanying text.

${ }^{179}$ See Frances Lee Ansley, Stirring the Ashes: Race, Class and the Future of Civil Rights Scholarship, 74 CORNELL L. REV. 993, 1031 n.155 ("[C]ivil rights cases and statutes eventually made significant inroads on formal boundaries of 'public' and 'private' spheres."). One only need look at the headlines of the times to grasp the urgency of such imperatives. Racial strife in this country was rampant when Jones and Sullivan were decided. In this analysis we "must be mindful of the "events and passions of the time'...." General Bldg. Contractors v. Pennsylvania, 458 U.S. 375, 386 (1982) (quoting United States v. Price, 383 U.S. 787, 803 (1966)).

${ }^{180}$ Some may argue that the Court in Sullivan, by rejecting the trial court's conclusion that Little Hunting Park was a "private social club," Sullivan, 396 U.S. at 236 ("There was no plan or purpose of exclusiveness. It is open to every white person within the geographic area, there being no selective element other than race."), went beyond the property scope of $\S 1982$ by tying pool membership to a leasehold. "By attempting to deal with the problem of discrimination in the provision of recreational facilities under $\S 1982$, the Court is forced, in the context of a very vague statute, to decide what transactions involve 'property' for the purposes of $\S 1982$." Id. at 248 (Harlan, J., dissenting).

The Court's willingness to make this leap illustrates the normative power of the desire to eradicate racial discrimination in all sectors. The Court further expanded its definition of "property" in Tillman v. Wheaton-Haven Recreation Ass'n, 410 U.S. 431 (1973). In this case, the property link to recreational facilities was even more tenuous (residence simply enhanced one's ability to join the club, it did not confer automatic membership). Nonetheless, the Court concluded that since membership in a racially exclusive club enhanced property values of those allowed to join the club, the racially restrictive code of the pool was in violation of, inter alia, $\$ 1982$. See id. at 437.

A similar expansion of state oversight of private contracts occurred outside of the real estate context in the Court's interpretation of $\$ 1981$. In 1976 the Court held that $\$ 1981$ "prohibits racial discrimination in the making and enforcement of private con- 
Stated as such, the hypernorm challenges the primacy of the private sphere where "people [a]re free to act in a self-interested manner, without regard to the interests, needs or expectations of others." essence, it challenges our individualism. The imposition of this hypernorm-a universal normative value-seems to require a sacrifice of self to the community.

Left unchecked this hypernorm is like a runaway engine roaring towards the destruction of our individually based communities. How can we exalt individualism and at the same time bow to norms that subordinate the individual to the greater society? Clearly there must be limitations on the hypernorm.

\section{Limits of State Intervention}

In 1981, in City of Memphis v. Greene, ${ }^{182}$ the Supreme Court applied the brakes to private actions based on $\S 1982$. While conceding that private action is subject to review under $\S 1982$, the Court required a showing of racial motivation to establish a prima facie case. ${ }^{183}$ In Greene, a white neighborhood sought to close a street-an action that would have denied access to people living in the adjacent neighborhood (who, notably, were primarily African-American). The Court found that there was "no evidence that the closing was motivated by any racially exclusionary desire." Rather, in language reminiscent of Belle Terre, ${ }^{185}$ the Court wrote that " $[t]$ he city's decision to close West Drive was motivated by its interest in protecting the safety and tranquillity of a residential neighborhood." 186

Justice Marshall, writing for the dissent, voiced no disagreement with the requirement of a showing of discriminatory intent. Rather, he focused on the presence of unspoken racial motivation. ${ }^{187}$ Whether or not there was a sufficient showing of racial motivation in Greene is irrele-

tracts." Runyon v. McCrary, 427 U.S. 160, 168 (1976). This decision was revisited and reaffirmed in Patterson v. McLean Credit Union, 491 U.S. 164 (1989).

${ }^{181}$ Joseph William Singer, Legal Realism Now, 76 CAL L. REV. 465, 481 (1988) (book review).

${ }_{182}^{182} 451$ U.S. 100 (1981).

${ }^{183}$ See id. at 119-20.

184 Id. at 114.

${ }^{183}$ Village of Belle Terre v. Boraas, 416 U.S. 1, 9 (1974) (describing Belle Terre as "[a] quiet place where yards are wide, people few and motor vehicles restricted" and noting that these are "legitimate guidelines in a land-use project addressed to family needs").

${ }^{186}$ Greene, 451 U.S. at 119.

187 Id. at 141-55. 
vant to the present discussion, for we have found the boundary of the hypernorm: conduct that may have discriminatory impact is permissible if there is no discriminatory motive. This is not a radical thought. Zoning laws that promote economic segregation likewise promote racial segregation $^{188}$ and, for the most part, legal attempts to manipulate zoning laws to eradicate this segregation have had only limited success. ${ }^{189}$ I submit that this lack of success is due to the fact that the motive of the segregation is economic, and economic segregation does not challenge American society's value structure as does racial segregation. Without racial motivation our societal hypernorm is not violated.

Application of this hypernorm will attempt to shape collective behavior beyond individual will. This notion conjures up the image of a salmon (manipulation of collective behavior) swimming upstream against the current (power of individual rights). The difficulty is that the hypernorm attempts to ban segregation (group dynamic) while still allowing prejudice (individual choice). Separating segregation from prejudice is difficult because there is no way to clearly disaggregate "voluntary" segregation (a result of prejudice) from "involuntary" segregation (a result of market forces). ${ }^{10}$

The function of the hypernorm is not to destroy individual choice. Rather, it serves to stake out the boundaries of individual choice as that choice "transforms" into collective behavior. ${ }^{191}$ Housing discrimination

- ${ }^{189}$ It is commonly assumed that economic segregation contributes to racial segregation because the African-American poverty rate is higher than the white poverty rate. See BurEaU of THE CENSUS, U.S. DEP'T OF COMMERCE, CURRENT POPULATION REPORTS, CONSUMER INCOME, SERIES P60-188, INCOME, POVERTY, AND VALUATION OF NONCASH BENEFITS: 1993, at xvi tbl.C (1995) (stating that in the United States in $1993,9.9 \%$ of whites (not of Hispanic origin) lived in poverty, while $33.1 \%$ of the black population lived in poverty). But see Sander, supra note 146, at 886 ("[M]iddle class blacks experience virtually the same level of segregation as the black community as a whole."); see also Phelan \& Schneider, supra note 137.

${ }^{189}$ See e.g., cases cited supra note 7 (requiring zoning regulations to allow for the development of low and moderate income housing); Britton v. Town of Chester, 595 A.2d 492 (N.H. 1991) (striking down as exclusionary a zoning ordinance which, through density limitations, excluded persons of low or moderate income).

190 Richard Sander contends that such a distinction cannot be maintained and that discrimination and segregation cannot be addressed in isolation. " $[N]$ either discrimination nor segregation can be addressed in isolation from one another. Even if most discrimination is eliminated, the residual can trigger the cycle of resegregation and leave the ghetto intact." Sander, supra note 146, at 903. I assert that we must try. Although the hypernorm can, and should, shape collective behavior, it cannot eradicate individual will.

${ }^{101}$ Transformation of individual choice into collective behavior is premised upon the theory that "[i]ndividual choice is a microcosmic facet of collective or social choice." WARREN J. SAMUELS, 1 ESSAYS ON THE ECONOMIC ROLE OF GOVERNMENT 58 
cannot and should not be tolerated, let alone aided, by the government. For societal good, the individual choice of racial prejudice must be sacrificed insofar as it becomes the collective behavior of housing discrimination. However, since sacrifice of individual choice is premised upon racial prejudice, we should be willing to allow choices not based upon racial/ethnic prejudice to remain. ${ }^{192}$

\title{
IV. THE STRUgGLE TO RESTRUCTURE LOCAI GOVERNMENT
}

\author{
"Is it larger than a breadbox?" \\ -Twenty Questions
}

We are trying to fit the round peg of collective individuality into the square hole of the present state of local government law. To a certain extent, the law does recognize local government as a collective individual, free to determine its fate without intervention from those outside the community. ${ }^{193}$ But local government falls short of allowing complete freedom on two somewhat contradictory fronts. First, while the law does, in some instances, validate the revealed choice of those choosing to move to the suburbs by treating suburbs and city separately instead of regionally, ${ }^{194}$ it penalizes others for an individual's choice by not forcing upon the migrator an internalization of the externalities produced by such migration. Second, the law, through secession stat-

\section{(1992).}

${ }^{192}$ There is of course, the legal quagmire that surfaces in any discrimination case: Is it enough to prove discriminatory impact or must actual discriminatory motive be proven? See, e.g., Griggs v. Duke Power Co., 401 U.S. 424 (1971) (holding that when an employer's facially neutral rule is shown to have a racially disproportionate effect on job applicants, that rule will violate Title VII of the Civil Rights Act of 1964 unless it is shown to be related to job performance). Lowering the bar to allow impact alone may permit many types of "discrimination" (e.g., economic) to eviscerate individual choice so that the individual will disappear from the equation. However, as the dissent in City of Memphis maintained, racial and ethnic discrimination, more often than not, is not blatant, and disparate impact may be the only evidence. See City of Memphis, 451 U.S. at 151-53 (Marshall, J., dissenting).

${ }^{199}$ For example, courts frequently uphold the validity of zoning codes. See Village of Euclid v. Ambler Realty Co., 272 U.S. 365 (1926) (upholding a zoning regulation in spite of land owners' protests that the regulation reduced property values). But see Mount Laurel and progeny, supra note 7 (striking down narrow zoning laws and holding that a municipality's land use regulations must provide a realistic opportunity for low and moderate income housing).

${ }^{194}$ This dichotomous treatment, some say, has been the downfall of past urban strategy. See Michael E. Porter, The Competitive Advantage of the Inner City, HARV. BuS. REV., May-June 1995, at 55, 55 ("Lacking an overall strategy, such programs have treated the inner city as an island isolated from the surrounding economy and subject to its own unique laws of competition."). 
utes, limits the individuality of those consumers who may want to remain physically, but not politically, in the city. The new local government structure, therefore, should combine features of deurbanization with a mechanism to internalize negative externalities while maintaining faith to our societal hypernorms. In effect I am trying to build a regional "mosaic culture." communities while the grout that holds them together insures that negative externalities are spread evenly across the mosaic.

\section{A. The Neighborhood as a Political Entity}

What is the optimal level at which to express this collective individualism? Obviously, as Professor Frug noted, absolute individual self determination is "pure fantasy." the homogeneity necessary to allow individualism to shine through. ${ }^{197}$ The legal goal is to superimpose distinguishing economic and social characteristics on a region to give spatial life to collective individualism.

The neighborhood would be the optimal level for city government. The idea of using the neighborhood as the optimal spatial unit is certainly not new. ${ }^{198}$ Social functionalist planners organized the city around the neighborhood unit because the neighborhood fosters community at the local level by increasing participation in democracy and serving to distribute scarce resources. ${ }^{193}$. What is unique about the

195 BRIAN J.L. BERRY, THE HuMaN CONSEQUENCES OF URBANIzATION 66 (1973) (defining "mosaic culture" as "a society with a number of parallel and distinctly different life styles").

${ }^{196}$ Frug, supra note 2, at 1069.

${ }^{197}$ See PARK, supra note 46 , at 90 ("The difficulty of maintaining in the city the intimate contacts which in the small town insured the existence of a common purpose and made concerted action possible is certainly very great.").

198 See generally HERBERT J. GANS, THE URBAN VILLAGERS at ix (1962) (reporting a study of a now defunct low-income Boston neighborhood); HOWARD W. HALLMAN, NEIGHBORHOOD GOVERNMENT IN A METROPOLITAN SETTING 12 (1974) (asserting "[n]eighborhood government should be established in the larger cities of the United States [as it] would contribute to improved urban governance"); DAVID MORRIS \& KARL HESS, NEIGHBORHOOD POWER: THE NEW LOCALISM 5, 99 (1975) (attempting to define the concept of "neighborhood" and noting that neighborhoods can be based upon direct participation); William Grigsby et al., The Dynamics of Neighborhood Change and Decline, 28 PROGRESS IN PLAN. 1, 20 (1987) ("[D] espite the long history of interest in urban neighborhoods, consensus about precisely what they are or should be does not exist."); Yates, supra note 37. The neighborhood continues to be a fertile area of social research. See, e.g., Christopher Mele, Globalization, Culture and Neighborhood Change: Reinventing the Lower East Side of New York, 32 URB. AFF. REV. 3 (1996) (discussing changes in the "East Village" and reactions of inhabitants).

${ }^{199}$ For a discussion of this topic, see Keith Aoki, Race, Space and Place: The Relation- 
political neighborhood, as envisioned here, is that this neighborhood would function politically and legally autonomously from the city, or local government, to which it once belonged.

Furthermore, neighborhoods are also rich repositories of local values. ${ }^{200}$ The division of governmental powers should reflect such community values. ${ }^{201}$ While hypernorms would overrule conflicting community norms, the common values within the community would form the basis of self-definition. ${ }^{202}$

The next question is almost immediate: how do we decide what is (and what is not) a "neighborhood?" Moreover, who gets to decide the boundaries of these newly empowered municipalities, the new "Political Neighborhood"? There are no generally accepted legal or economic principles for determining a municipality's geographic dimensions or even whether that unit should exist. ${ }^{203}$ This is relatively uncharted legal

ship Betzeen Architectural Modernism, Post-Modernism, Urban Planning, and Gentrification, 20 FORDHAM URB. L.J. 699, 72427 (1993) (citing work of social functionalist planners such as Clarence Stein in Radburn, New Jersey).

${ }^{200}$ See GANS, supra note 55, at 14-15 (explaining that "the various ethnic groups [in a poor Boston neighborhood] at various points ... had common values").

${ }^{201}$ See Arthur Maass, Division of Powers: An Areal Analysis, in AREA AND POWER 9, 9 (Arthur Maass ed., 1959) ("[D]ivision of powers ... is instrumental of community values; and the form of the division at any time should, and likely will, reflect the values of that time.").

${ }^{202}$ This raises the questions of whether such variance would trigger an equal protection claim and, assuming it does, the level of scrutiny the courts would impose. Although the answer to this dilemma is outside the scope of this Article, Professor Neuman offers the following insight:

Thus, what I am proposing is that intrastate variations in the scope of fundamental rights that result from the independent decisions of self-governing political subdivisions should be excused from heightened scrutiny and subjected only to the rational basis test. They should be excused because they are $j u s t i-$ fied by their contribution to the goal of local self-determination, though not in a way that would withstand heightened scrutiny under the equal protection clause. An exception to the scrutiny that would otherwise be applied is therefore required when geographical classifications affect fundamental rights.

Gerald L. Neuman, Territorial Discrimination, Equal Protection, and Self-Determination, 135 U. PA. L. REV. 261, 311-12 (1987).

${ }^{203}$ See Who Rules at Home?, supra note 3, at 395 (stating "the concept of selfgovernment does not dictate who is the 'self' that does the governing"); George C. Galster, What Is Neighbourhood? An Externality-Space Approach, 10 INT'L J. URBAN \& REGIONAL RES. 243, 243-45 (1986) (stating that no consensus exists regarding the definition of a neighborhood and arguing for a new conceptual definition); see also, e.g., Grigsby et al., supra note 198, at 20 ("[D] espite the long history of interest in urban neighborhoods, consensus about precisely what they are or should be does not exist."). This definitional question is not unique to creation of local governments. As the breakup of the former Yugoslavia has shown, on the international level there is no universally valid criteria for identifying a genuine nation. 
territory. ${ }^{204}$ The law must walk the fine line between realist concerns (what are the physical, objective boundaries?) and instrumental concerns (what should be the boundaries to achieve the goals of government?) without falling into undue reliance on the descriptive (what do residents think are the boundaries?).

The realist sees a neighborhood as bounded by tangible, objective markers: streets, rivers, etc. This argument runs parallel to the "natural areas" argument of Park. ${ }^{205}$ Use of objective markers, however, may mask true collective individualism. For while objective markers may be easy to use, they are imposed from the outside. As has been asserted by scholars writing subsequent to Park, what makes these "natural areas" natural exists in the mind of the researcher. ${ }^{206}$ What would be determined by the realist definition of a neighborhood is less what the neighborhood is than what, for bureaucratic efficiency, an outsider thinks that it is.

An instrumental determination is, admittedly, less objective. Here the boundaries would be drawn to reflect the underlying goal of decentralization of government. How should the neighborhood achieve the goals of decentralized government? If, for example, the Jeffersonian ideals of suffrage and participation ${ }^{207}$ were the goal, then the neighborhood would be numerically limited by the optimal number of inhabitants to produce the highest levels of political participation.

I submit however, that our goal is more subjective. To be sure, the efficiency arguments of the realists must be given their due for this end to be at all workable. Yet, the "should" question is as important as the objective goals and must be dealt with in tandem. To truly express col-

${ }^{204}$ There have been attempts in the economics and social science literature to determine municipalities' geographic dimensions. See, e.g., Galster, supra note 203, at 246-47 (attempting to delineate neighborhoods using an "externality space" model); Albert Hunter, The Urban Neighborhood: Its Analytical and Social Contexts, 14 URB. AFF. Q. 267, 267 (1979) (summarizing "three approaches to the study of neighborhoods: (1) typologies, (2) stages of change, and (3) functions"). As Professor Frug points out: "The fact that some projects might fail can no more serve as an argument against these experiments than the fact that some projects might succeed, although both arguments are commonly made when such city ventures are proposed." Frug, supra note 2 , at 1151 .

${ }^{205}$ See PARK, supra note 46, at 172 ("Natural areas are the habitats of natural groups. Every typical urban area is likely to contain a characteristic selection of the population of the community as a whole.").

${ }_{200}$ See WEIHER, supra note 47 , at 43 ("Most subsequent research ... casts serious doubt upon the validity of the natural area concept.").

${ }^{207}$ Jefferson argued that suffrage is the true foundation of popular government. See MATTHEWS, supra note 68 , at 78. 
lective individualism we must answer the normative questions: "power to whom?" and "power for what?"208

In the quest to define the political neighborhood, it is tempting to rely on the inhabitants for the definition. After all, it is the inhabitants who make up the collective individual which is the neighborhood. While self-definition can be notoriously unreliable, ${ }^{20+9}$ it is not totally without merit.

This concept is neither as arbitrary nor as circular as it may initially appear. After all, we each define our respective space every day by what we are and, sometimes more importantly, by what we are not. ${ }^{210}$ The insistence on preserving present local boundary lines to define local government is, in fact, more arbitrary and circular than reliance on selfdefinition. Most people disregard these boundaries countless times each day, while forming their own idea of region, which they organize according to their personal concept of neighborhood. Instead of imposing objective definitions from the outside, we should strive toward a subjective definition of neighborhood created by those seeking to be defined. This subjective definition must be coupled with a realistic acknowledgment of the need for some efficiently determined population goals, while keeping in mind that our aim is the expression of individualism. ${ }^{211}$

This process will inevitably generate dissent because there is no democratic way of deciding who gets to draw the boundaries. ${ }^{212}$ The dissent can be incorporated into the process of neighborhood defini-

${ }^{208}$ Wood, supra note 8, at 54 ("Answers to the normative questions of 'power to whom?' and 'power for what?' are to be modified continually in the light of contemporary values ....").

${ }^{209}$ For example, people in one Chicago study defined the boundaries of their neighborhood quite inconsistently. See WEIHER, supra note 47, at 26 (discussing a 1972 study of the South Shore community in Chicago); see also Ernesto G. Arias, Bottom-up Neighbourhood Revitalisation: A Language Approach for Participatory Decision Support, 33 URB. STUDIES 1831, 1837 (1996) (describing various mechanisms, including computer simulations, designed to assist neighborhoods in the task of self-definition).

${ }^{210}$ According to Professor Frug, identity is not only made up of sameness, it is also composed of and dependent upon differences. See Frug, supra note 3, at 259-60.

${ }^{21}$ George Galster uses a similar tripartite economic model to define neighborhood. He formulates algorithms to estimate congruence ("the degree to which an individual's externality space corresponds to predefined geographic boundaries"), generality ("the degree to which an individual's externality spaces for different types of externalities correspond") and accordance ("the degree to which externality spaces for different individuals in the same area correspond"). Galster, supra note 203, at 246-54.

912 See Voting Rights, supra note 3, at 802 ("[T]here is no uncontestably 'democratic' way of deciding who [draws boundaries]."). 
tion if the creation of the neighborhood is premised upon voluntary association. The Lockean requirement of voluntary association for a legitimate government, when used as a premise for such neighborhoods, will insure that whatever the definition, the political neighborhood will be treated as a body politic.because all parties have consented by joining the final product. ${ }^{213}$ Even if people initially differ on their definition of the boundaries of the neighborhood, ${ }^{214}$ it is this final consensus that will define the neighborhood.

\section{B. Allowing Formation of the Political Neighborhood}

Creation of the political neighborhood requires an analysis of the fundamental political philosophy underlying secession. ${ }^{215}$ While some scholars maintain that secession be predicated upon "fault," that "no-fault," nonconsensual secessions be granted. To be sure, a resident is always free to leave a jurisdiction. Secession, though, involves more than a group of dissatisfied residents moving out of the jurisdiction. By seceding, the group wants to leave the jurisdiction and

${ }^{213}$ See John Locke, An Essay Concerming the True Original, Extent and End of Civil Government $\$ \$$ 95-96, in SOCIAL CONTRACT: ESSAYS BY LOCKE, HUME, AND ROUSSEAU, supra note 1, at 56-57 (arguing that the consent of the individuals governed is a prerequisite for a legitimate government that may act by will of the majority). But the presence of involuntary members is necessary for a 'public' organization. See Robert C. Ellickson, Cities and Homeoumers Associations, 130 U. PA. L. REV. 1519, 1523 (1982) ("[T] he presence of involuntary members is ... a necessary condition for the use of the adjective 'public' in ordinary language ....").

${ }^{214}$ For example, people who lived in the same Chicago suburbs defined the boundaries of the community differently. See WEIHER, supra note 47, at 26; see also Grigsby et al., supra note 198, at 23 (cautioning that while subdivision of communities into neighborhoods for planning purposes is commendable, "such an exercise may easily lead to erroneous inferences about what these geographic units really mean in the lives of the residents").

${ }^{215}$ For a discussion of the Staten Island case, see Voting Rights, supra note 3 (advocating that Staten Island meet a tough standard before it be allowed to secede); Florence L. Cavanna, Note, Home Rule and the Secession of Staten Island: City of New York v. State of New York, 8 TOURO L. REV. 795 (1992) (discussing New York's home rule); Jeffrey Underweiser, Note, The Legality of Staten Island's Attempt to Secede from New York City, 19 FordHAM URB. L.J. 147 (1991) (arguing that New York's Home Rule Doctrine should be invoked to stop Staten Island's secession). Some state courts have advocated a liberal construction of secession laws, which allows more flexibility for secession. See, e.g., Harris Trust \& Sav. Bank v. Village of Barrington Hills, 549 N.E.2d 578, 581-82 (Ill. 1989) (recounting the court's long history of interpreting disconnection statutes liberally).

${ }^{216}$ Briffault contends that "[s] ecession should be predicated on a showing that the municipal majority is systematically exploiting the minority, or at the very least that the majority is advancing only its own values and consistently ignoring the minority's needs and interests." Voting Rights, supra note 3, at 847. 
wants to take its property along. ${ }^{217}$

Opposition to secession can rest on democratic ideals or upon economic arguments of equity and externalities. ${ }^{218}$ I will discuss these arguments in turn as they apply to the formation of the political neighborhood. Abraham Lincoln argued that secession is fundamentally at odds with democratic self-government based on majority rule. Lincoln stated: "[T] he central idea of secession, is the essence of anarchy." ${ }^{219}$ It is difficult to demand on democratic principles that a mistreated and/or ignored minority has the duty to stay and accept the majority's rule. Some argue that a minority that has suffered no harm, however, should not be allowed to secede because secession is not the democratic manner of expressing dissatisfaction. ${ }^{220}$

In other words, should secession be permitted even when there has been no showing that the existing municipality has harmed the secessionists in some way? This argument misses the point because secession in the present context should not be dependent on the existing municipality's failure to perform its duties. ${ }^{221}$ Instances will arise where the existing municipality has fulfilled every duty to a group that nevertheless wants to secede, analogous to a no-fault divorce. This secession should be granted because secession is based, not upon a failure of the majority, but upon a community's desire to express an individuality that it cannot express while remaining in the existing municipality. ${ }^{222}$ The

${ }^{217}$ See Voting Rights, supra note 3, at 788 ("In a secession, people are determined to leave the jurisdiction and to take their territory with them."); see also Allen Buchanan, Toward a Theory of Secession, 101 ETHICs 322, 326 (1991) ("The secessionist does not deny the state's authority as such, but only its authority over her and the other members of her group and the territory they occupy." (emphasis added)).

${ }^{2} 8$ See Voting Rights, supra note 3 , at $833-48$ (discussing the case against secession in terms of democracy, equity, efficiency and externalities). But see Allen Buchanan, SelfDetermination and the Right to Secede, 45 J. INT'L. AFF. 347, 353-58 (1992) (discussing various justifications for secession including rectificatory justice (reappropriation of stolen property by the rightful owners) and discriminatory redistribution (unfair taxation); Buchanan, supra note 217, at 327-32 (same).

219 Voting Rights, supra note 3, at 845-46 (quoting Abraham Lincoln, First Inaugural Address, reprinted in ABRAHAM LINCOLN, SPEECHES AND WRITINGS, 1859-1865, at 220 (Library of America 1989)).

220 See Voting Rights, supra note 3, at 846-47.

${ }^{221}$ In the international arena the question of justification of secession in the absence of state-perpetuated injustice is best exemplified by Quebec's recent attempt to secede from Canada on the basis of cultural preservation. The difficulty with this ground for secession is finding a clear definition of "culture." Allen Buchanan asserts that cultural preservation provides an adequate justification for national secession under stringent conditions. See Buchanan, supra note 217, at $357-58$ (discussing secession for cultural self-preservation).

${ }_{222}$ For a different opinion, see Voting Rights, supra note 3, at 818-19 (presenting the 
response to this democracy argument recalls the purpose behind the political neighborhood's creation: to allow full and free expression of individuality. Secession in this context is not at odds with democracy because it does not reject majority rule. Rather it rejects the majority itself.

The creation, and especially the placement of externalities upon those uniquely unable to bear the costs is the most powerful argument against "no-fault" secession. As stated before, there will be persons who have neither the social nor the economic wherewithal to form a new political neighborhood. ${ }^{224}$ By default these individuals will remain in what was the old municipality. ${ }^{225}$ The externalities of secession are not internalized and will be borne by those outside the new political neighborhood. To overcome this problem we must require that those who secede will contribute to the cost of services for those left behind. Here, collective individualism collides with collective public interest. Therefore, an intermediate, federative tier of government must be created to effectuate region-wide wealth redistribution for social service expenditures. To use Rousseau's terminology, the political neighborhood is based on the will of all, the sum of the individual wills (omnes $u t$ singuli), and the intermediate tier is based on the will of general intention "directed to the attainment of the general good" (omnes ut universi). ${ }^{22 \pi}$

The precise mechanics of the intermediate tier's revenue-raising (whether through a sales tax, an income tax or a property tax) are not as important as the creation of a regional wealth redistribution mecha-

idea that secession laws should be like annexation laws, that is, requiring first, a referendum in the area looking to secede, second, consent of the municipality left behind, and third, state-level review that could overturn a denial of consent on the basis of the "overall public interest" of the region).

${ }_{223}$ See Voting Rights, supra note 3, at 836-42 (noting that secession raises equity concerns regarding the "redistribution of municipal wealth").

${ }_{224}$ Some urban researchers have found relatively lower mobility among lowerincome households. See Charles F. Adams et al., Flight from Blight and Metropolitan Suburbanization Revisited, 31 URB. AFF. REV. 529, 535-36 (1996) (discussing study results and noting that "migrants [to the suburbs] tend to be from the middle- and upperincome levels").

${ }^{225}$ An argument put forth for opposing secession is that secession may be resisted if it would be fatal to the larger political unit. Superficially, this line of logic begs the question. Furthermore, deeper analysis reveals that the ability to enter into interlocal agreements for police, fire, water, etc., would save municipalities from doom. For a discussion of this "self-defense" argument on the international level, see Buchanan, supra note 217, at 332-50.

${ }_{226}$ Sir Ernest Baker, Introduction to SOCIAL CONTRACT: ESSAYS BY LOCKE, HUME, AND ROUSSEAU, supra note 1, at xxxiii (discussing Rousseau's concept of the will upon which a state is based). 
nism. ${ }^{227}$ For while the secession of political neighborhoods may permit the expression of full individualism, it can create glaring negative externalities. Without the intermediate tier it is impossible to internalize these externalities. This tier, though, would have a very limited function, primarily serving as a conduit for regional wealth redistribution. To place any more power in the intermediate tier is to approach regional government. ${ }^{228}$ Regional government is the antithesis of empowering the collective individual.

The creation of this regional federation is not purely an altruistic endeavor on the part of the new political neighborhood. ${ }^{229}$ Our previous definition of self included not only what we are, but also what we are not. In defining ourselves, it is useful to compare ourselves to what we are not. ${ }^{230}$ Therefore, recognition of other individuals, other municipalities, creates an interdependence that is necessary for the recognition of self. The federative tier permits full expression of individuality while capturing the externalities created by such personal choice.

\section{Political REAlity and SOCIAL Justice}

"[T] he problem, therefore, of the present is to lead our law to hold a

927 In this respect, I suspect I join what Joan Williams calls the "third generation of twentieth century reformers who have sought to reformulate city status as a first step in redefining the body politic in order to solve pressing social problems." Williams, supra note 3 , at 150 (discussing Frug's reform ideas).

${ }_{228}$ In this respect I disagree with Professor Briffault. Although he also envisions a two-tier local government, he is willing to shift certain governmental functions to the regional level while reserving others to pre-existing local governments. See Who Rules at Home?, supra note 3 at 411-19 (discussing regional governments). I question how he can take power away from local governments while "assuring them continuing autonomy over a range of other functions." Id. at 413. Likewise, I disagree with the structure of Professor Frug's regional legislature. See Frug, supra note 3, at 294-300. I fear that by empowering the intermediate tier with discretionary functions (not merely administrative duties), we move away from decentralization and toward regional government.

${ }^{229}$ To avoid pure altruism the framework must be constructed to withstand any distributive (as opposed to redistributive) pressures that may develop over time. A distributive policy identifies "the class of potential recipients [as] virtually unlimited, so that there is no clearly definable group that comprehends themselves as taxed to support others without themselves benefiting." DOUGLAS J. WATSON ET AL., THE POLITICS OF REDISTRIBUTING URBAN AID 123-27 (1994) (discussing distributive versus redistributive policies). I advocate a redistributive policy where the taxed do not benefit directly from the revenue raised by the tax.

${ }^{230}$ For a fascinating discussion of this topic, see Frug, supra note 3, at 258-63 (describing the complexities inherent in defining identity). 
more even balance between individualism and collectivism."

-Roscoe Pound ${ }^{231}$

Now comes time for a pragmatic application of legal and social theory. ${ }^{232}$ I say "pragmatic," and not "practical," because "practical" carries the baggage of an economic efficiency analysis. The goal here is not to promote efficiency above all else. Rather, the goals should be the legal recognition of an individual's social and economic desires and the implementation of legal vehicles to further that recognition. ${ }^{233}$ There are two questions on the table: is a government structure premised upon individual cum collective choice possible? And even if it is, why would anyone opt for this form of government?

\section{A. The Paradox of a Collective Choice Democracy}

Democratic government is premised upon legislative enactment of collective will as determined by majority voting. Because codification of collective will is binding on dissenters it is distinct from a series of individual choices. ${ }^{234}$ Therefore, although individualism forms the basis of our newly empowered neighborhood, combining individual preferences into a democratic society may have paradoxical results if we try to find the will of the majority. ${ }^{235}$ The tension between individual choice

${ }^{231}$ RONALD CHESTER, INHERTANCE, WEALTH, AND SOCIETY 97 (1982) (quoting Roscoe Pound, The Spirit of the Common Law, 18 THE GREEN BAG 17, 24 (1906)).

${ }_{232}$ By using the term "pragmatic," I do not mean to invoke the philosophical definition of pragmatism in its strictest sense. Rather, I am employing the term in a more colloquial sense. As Richard Warner points out: "Sometimes the label connotes little more than taking a serious interest in practical politics and the realities of human wellbeing and suffering ...." Richard Warner, Why Pragmatism? The Puzzling Place of Pragmatism in Critical Theory, 1993 U. ILL. L. REV. 535, 539. However, even the more philosophical definition of pragmatism may be applicable insofar as pragmatism recognizes that law is "contingent not just upon the acts of legislatures or other authoritative entities, but also upon the surrounding social context, the content of an entire form of life.'" Stephen J. Schnably, Property and Pragmatism: A Critique of Radin's Theory of Propenty and Personhood, 45 STAN. L. REV. 347, 348 (1993) (quoting Margaret Jane Radin, Reconsidering the Rule of Law, 69 B.U. L. REV. 781, 808 (1989)).

${ }^{2 s 3}$ If the last statement sounds sanctimonious, please forgive me. I am taking to heart what Steven Smith found to be the function of legal pragmatism: "not to say things that lawyers and judges do not know, but rather to remind lawyers and judges of what they already believe but often fail to practice. The pragmatist is a kind of preacher." Steven D. Smith, The Pursuit of Pragmatism, 100 YALE L.J. 409, 411 (1990).

${ }^{234}$ See SHaUn Hargreaves HeAP ET AL., THE THEORY OF CHOICE: A CRITICAL GUIDE 199 (1992) ("A collective choice, as distinct from ... a series of individual choices ... has the characteristic that it holds for all members of a given group.").

${ }^{235}$ See Julian N. Eule, Judicial Review of Direct Democracy, 99 YALE L.J. 1503, 1520 (1990) (noting that because there is no fair way to combine individual preferences, "it may be impossible to reflect accurately such a thing as the will of the majority"); Rich- 
and collective will exists on two levels in the proposed structure of local government. First, regardless of how homogeneous the political neighborhood might be, there will inevitably be dissension between the community and the individual. Second, the federative tier's redistributive function counteracts individual choice because participation is mandatory regardless of residential location within the region. Hence, the willingness of an individual to allow herself to be bound by the will of the community (whether the neighborhood or the region) must be grounded in more than individual choice. I will address each source of tension in turn.

\section{The Individual Within the Political Neighborhood}

Rational, individual choice must at some point give way to collective choice and social justice. By acceding to the necessity of collective choice over individual choice, I do not give collective will lexicographic priority over individuality. ${ }^{236}$ I am simply acknowledging the connections between rational choice and theories of social justice. ${ }^{237}$ Just as a purely individualistic theory ${ }^{238}$ of society is ultimately unworkable in modern living, a purely utilitarian collective theory ${ }^{239}$ does not give individual choice its proper respect. To find a theory of social justice we should go back to the Social Contract of Rousseau:

Some form of association must be found as a result of which the whole strength of the community will be enlisted for the protection of the person and property of each constituent member, in such a way that each, when united to his fellows, renders obedience to his own will, and remains as free as he was before. ${ }^{240}$

ard H. Pildes \& Elizabeth S. Anderson, Slinging Arrows at Democracy: Social Choice Theory, Value Pluralism, and Democratic Politics, 90 COLuM. L. REV. 2121, 2124 (1990) ("[S]ocial choice theorists claim democracy cannot avoid being defective ...."); see also Arrow's "Impossibility Theorem," supra note 28 and accompanying text.

${ }_{236}$ For Rawls, liberty always has lexical order and can only be restricted for the sake of liberty. See JOHN RAWLS, A THEORY OF JUSTICE 250 (1971) (listing only two cases in which liberty can be restricted: when "(a) a less extensive liberty must strengthen the total system of liberty shared by all, and [when] (b) a less than equal liberty must be acceptable to those citizens with the lesser liberty").

${ }_{237}$ See HEAP ET AL., supra note 234, at 260 (postulating that there are links between theories of social justice and rational choice, with some links being stronger than others).

${ }^{238}$ That is, society is a collection of individuals; society itself has no purpose.

${ }^{239}$ That is, society is simply an aggregate of the welfare of individuals without distinguishing amongst those constituents.

${ }^{240}$ SOCIAL CONTRACT: ESSAYS BY LOCKE, HUME, AND ROUSSEAU, supra note 1, at 180. 
The political neighborhood would be a voluntary scheme with autonomous members and self-imposed obligations that premise social cooperation upon mutual advantage. ${ }^{241}$

Grounding our new framework of local government on such contractarianism allows us to express two fundamental ideals. First, the value of liberty is maintained as it is will, not force, that underlies the government. Second, the collective value of justice is preserved as the base of our society is right, not might. ${ }^{242}$ The social contract that binds the community assures that while a member may sacrifice a portion of his or her individuality for the good of the community, society will only demand so much as is necessary to achieve social justice. ${ }^{243}$

As Rawls stated, however,

[W] are not to think of the original contract as one to enter a particular society or to set up a particular form of government. Rather, the guiding idea is that the principles of justice for the basic structure of society are the object of the original agreement. They are the principles that free and rational persons concerned to further their own interests would accept in an initial position of equality as defining the fundamental terms of their association. These principles are to regulate all further agreements; they specify the kinds of social cooperation that can be entered into and the forms of government that can be established. This way of regarding the principles of justice I shall call justice as fairness. ${ }^{24}$

A recent contribution to the contractarian literature is David Gauthier's Morals By Agreement. ${ }^{245}$ Although not without critics, ${ }^{246}$ Gauth-

${ }^{241}$ As Rawls has stated:

[A] society satisfying the principles of justice as fairness comes as close as a society can to being a voluntary scheme, for it meets the principles which free and equal persons would assent to under circumstances that are fair. In this sense its members are autonomous and the obligations they recognize selfimposed.

RAWLS, supra note 236, at 13-14.

${ }^{242}$ See id. at 5 ("[Societies] understand the need for, and ... affirm, a characteristic set of principles for assigning basic rights and duties and for determining ... the proper distribution of the benefits and burdens of social cooperation.").

${ }^{243}$ This argument is along the lines of the Hobbesian necessity of a social contract to induce social cooperation. In that model, the "role of sovereign power is ... to supply some assurance to each individual that others will keep... the bargain." See HEAP ET AL., supra note 234, at 202-03.

${ }^{244}$ RAwLS, supra note 237 , at 11.

${ }^{245}$ DAVID GAUTHIER, MORALS BY AGREEMENT 9 (1986) (presenting a contractarian rationale for morality where "[morality] emerges... from the application of the maximizing conception of rationality to certain structures of interaction [and where the a]greed mutual constraint is the rational response to these structures").

${ }^{246}$ See Allen Buchanan, Justice as Reciprocity Versus Subject-Centered Justice, 19 PHIL. \& PUB. AFF. 227-28 (1990) (referring to Gauthier as a proponent of the idea of justice as 
ier contends that justice is the outcome of a rational bargain among voluntary contributors. ${ }^{247}$ In our voluntary political neighborhood, individuals should be willing to sacrifice their goal of maximizing individual utility based not upon benevolence, but rather upon realization of a mutual advantage. The bargain model acknowledges self-interest, but fits it into the framework of the necessity for social living.

\section{The Individual Within the Region}

Although a contractarian notion of community cooperation may easily apply within the political neighborhood, the concept of mutual advantage requires further refinement to fit around the redistributive goals of the federative tier. The Rawlsian, contractarian, notion of justice is that cooperation is founded on a voluntary system of fairness. ${ }^{248}$ Fairness, though, is a subjective term. ${ }^{240}$ To those on the receiving end of intraregional wealth redistribution, the system may certainly appear fair. However, to those on the paying end, the fairness may be harder to prove. What is the basis for asserting that those who are better off have the duty to help those who are less fortunate? What is the mutual advantage? ? $^{250}$

reciprocity-"a strain of thought... that threatens to shatter the basic conceptual framework within which our legal system and commonsense morality formulate the problems of justice"); see also BRIAN BARRY, JUSTICE AS IMPARTIALITY 42-45 (1995) (arguing that there are serious flaws in Gauthier's theory of justice as mutual advantage).

He explains:

The just person is fit for society because he has internalized the idea of mutual benefit, so that in choosing his course of action he gives primary consideration to the prospect of realizing the co-operative outcome. If he is able to bring about... an outcome that is both (nearly) fair and (nearly) optimal, then he chooses to do so; only if he may not reasonably expect this does he choose to maximize his own utility.

GAUTHIER, supra note 245 , at 157 .

${ }^{248}$ See supra note 244 and accompanying text.

${ }^{249}$ One definition of fairness that can be applied is a distribution of goods that is both envy-free (no one prefers another's bundle to their own) and Pareto-optimal (when one person's welfare increases, no one's decreases, and social welfare increases). See HEAP ET AL., supra note 234, at 319-22 (describing the overlap between justice and fairness).

${ }_{250}$ "One essential feature of a mutual-advantage theory is that there is no place for purely redistributive transfers of income-for transfers which impose a cost on some people so as to benefit others." HEAP, supra note 234, at 278. Critics of Gauthier point to the unjust outcome when basing justice on mutual advantage. See supra notes 241 and 246 and accompanying text. If a severely handicapped person cannot contribute to the cooperative effort, does this mean she may justly be excluded from the fruits of that effort? Fortunately, I do not believe we have to reach this perplexing question. As discussed infra, the contribution of the poor is in acquiescing to the political and 
We can approach the answer from two directions. The first would be to determine whether those receiving wealth redistribution contributed to the cooperative effort to establish the mutual advantage. The answer is yes. The cooperative contribution of the region's poor is the sanction by the poor of an insular political neighborhood. The contribution of the poor is their consent to economic exclusion. ${ }^{251}$ In exchange for this exclusion, the region's well-off must contribute to the economic externalities caused by the exclusion.

Alternatively, there is a second theoretical rationale for the imposition of the redistributive tier. This theory is Rawls's refinement of the idea of justice as mutual advantage, and it is expressed in his difference principle. ${ }^{252}$ The difference principle allows more productive people to earn more than less productive people only if the poorest people in society are thereby made less poor. "[N]o amount of gain to the betteroff can be justified if it is achieved at any cost to the poor." ${ }^{253}$ The difference principle expresses the concept of social reciprocity in economic gain. ${ }^{254}$

With the addition of the concept of reciprocity, as expressed by the difference principle, the wealthier residents cannot gain without also giving a benefit to the poorer residents. The creation of the political neighborhood benefits those within the neighborhood by allowing greater expression of individual choice. In accordance with the difference principle this gain cannot be at the expense of the poor. The reciprocity is the federative redistribution tier.

The difference principle is grounded on its requirement that a cooperative society benefits all of its members. "Thus the more advantaged ... man cannot say that he deserves and therefore has a right to a scheme of cooperation in which he is permitted to acquire benefits in ways that do not contribute to the welfare of others." 255

economic insularity (notwithstanding the federative tier) of the political neighborhood.

${ }^{251}$ In effect this is the end of inclusionary zoning requirements such as those in Mount Laurel.

${ }^{252}$ RAWLS, supra note 236, at 83 ("Social and economic inequalities are to be arranged so that they are ... to the greatest benefit of the least advantaged ....").

${ }^{259}$ HEAP ET AL., supra note 234, at 272 (contrasting Rawls's theory with utilitarianism).

${ }_{234}$ See RAWLS supra note 236, at 102 ("Thus we are led to the difference principle if we wish to set up the social system so that no one gains or loses from his arbitrary place in the distribution of natural assets of his initial position in society without giving or receiving compensating advantages in return.").

${ }^{253} I d$. at 104 . 


\section{B. Dissatisfaction with the Status Quo}

If mutual advantage and reciprocity in society convince the well-off to participate in a regional wealth redistribution scheme (or at least justify such participation), why not merely impose this requirement within the present state of local government? Why should we tear down the present state and rebuild along the parameters of a political neighborhood? Or, alternatively, if there is such a societal cooperative requirement, why not erase all local boundaries and meld into one big regional government?

The present state of local government represents the worst of both worlds. On the one hand, residents, many of whom have sought security in the suburbs, see frontal attacks on their individual will by city politicians. ${ }^{256}$ On the other hand, the poor in the city suffer because the tax base necessary to support adequate social services has fled to the suburbs. The political neighborhood would answer both of these concerns by guaranteeing expression of individual will while requiring participation in regional wealth redistribution.

Regional government also fails to overcome regional economic and legal problems. Some may point to the interjurisdictional tax-sharing cooperation effort of the Minneapolis-St. Paul region as an example of workable, and working, regional government. Its success, however, has yet to be duplicated on a large scale in other regions. ${ }^{257}$ As with any wealth redistribution system, these types of efforts will survive only as long as substantial numbers of nonbeneficiaries remain motivated and willing to pay. ${ }^{258}$ These "nonbeneficiaries," placed within the new political neighborhood, on the other hand, will be motivated to continue such participation due to the benefit of political and economic insularity.

The answer comes back to what is the foundation of local government: the individual. Proving mutual benefit, which is the predicate to

${ }^{256}$ See Rich Henson, Suburbs and City Join for a Chat at the Convention Center, PHILA. INQUIRER, May 26, 1995, at B4 (indicating that Philadelphia Mayor Ed Rendell would like the city to "get a slice of suburban tax revenues").

${ }^{257}$ The Minnesota Fiscal Disparities program, begun in 1975 , is a tax-sharing policy that regionalizes a portion of the commercial-industrial tax base in the Minneapolis-St. Paul metropolitan area. Each year $40 \%$ of new commercial-industrial tax base is apportioned to the regional fiscal disparities pool. Tax revenues from the pool generated by a single regional tax rate are then distributed to municipalities based on local tax capacities. See ROBERT INMAN ET AL., FISCAL FUTURE FOR AMERICAN CITIES: LESSONS FROM THREE CITIES 19 (Wharton Real Estate Center Working Paper No. 189, 1994) (describing the Minneapolis project).

${ }^{258}$ See WATSON ET AL., supra note 229 , at 124-26. 
wealth redistribution, is problematic in regional government. In the absence of allowing the individual free expression in the choice of local government, the benefit to these "nonbeneficiaries" all but vanishes. Instead of attempting to prove the positive externalities of the central city to prod interlocal revenue sharing, ${ }^{259}$ we should allow local municipalities to fully realize their individuality and point to that as the benefit to obligate regional wealth redistribution.

As a response to those who argue that restructuring local government around the collective individual is politically unrealistic, I suggest we explore the alternatives. We cannot continue under the present system without regressing to economic apartheid: the haves in the suburbs, the have-nots in the city. The disparity between the income levels of suburban and city residents increases each year. ${ }^{260}$ On the other hand, broad-based regional government has found little acceptance outside of the Academy. ${ }^{261}$ This resistance to regional government comes from city dwellers and suburbanites alike. ${ }^{262}$ Local government as the collective individual is more politically attainable than regional government and promises social justice lacking in the status quo.

\section{CONCLUSION}

In our attempt to "save" the city we have lost sight of the elements that constitute the city. Why should we direct our scholarly energy, policy directives, or economic power toward revitalizing an anachronistic, dying species of legal definition? The city that some are trying desperately to save is not the classical city that was defined by its sphere of influence. It is the city of political boundary-making that is inapposite to

${ }^{259}$ See Theodore Hershberg, Regional Cooperation: Stategies and Incentives for Global Competitiveness and Urban Reform, 85 NAT'L CIVC REV. 25, 29 (1996) ("It is time for suburban Republicans to sit down with urban Democrats. Both sides would come to the table aware of shared interests.").

${ }_{200}^{20}$ In 1960 the per capita income of city residents was $105 \%$ of that of suburbanites. By 1980 it dropped to $90 \%$. In 1987 it fell again to $59 \%$. In some cities the contrast is even more stark. For instance, in 1990 the per capita income of Philadelphia city residents was $48 \%$ of their suburban neighbors. See Poindexter, supra note 5, at 10 (comparing the relative income levels of suburban and city dwellers over the past three decades).

${ }^{261}$ For a general discussion of voter resistance to regional government, see Kincaid, supra note 60 .

${ }_{262}$ See Peter Dreier, America's Urban Crisis: Symptoms, Causes, Solutions, 71 N.C. L. REV. 1351, 1360 (1993) (noting resistance of suburban residents to the creation of broad-based regional government); Ronald Smothers, City Seeks to Grow by Disappearing, N.Y. TIMES, Oct. 18, 1993, at A10 (stating that resistance will come from "urban blacks benefiting from a rising tide of political power"). 
modern social and economic development.

Instead we must tear down the walls created by happenstance and long-forgotten political will, and establish community as those within the community would define it. Such redefinition would clearly benefit those within the newly created communities, but the impact of the redefinition would be much broader. We could begin to solve the economic mismatch between the city and the suburbs-the city's disproportionate burden of regional poverty versus the suburbs' advantage of disproportionate regional wealth. Rather than viewing these difficulties as "city" problems, we redefine them as "regional" problems and solve them without regard to legally and politically created boundaries. But as long as the legal structure maintains the long recognized bright-line boundaries of the traditional city, any attempt at a regional solution will fail. City will stand as a proxy for the existence of the problems of poverty, crime and social dysfunction. Those who choose not to live in the traditional city boundaries will resist a recasting of social problems as an attempt to force a political, social and economic allegiance to an entity they have fled.

By legally empowering the collective individual, as expressed in choice of local government, we validate individual choice, ground local government law in determinative legal doctrine, and begin to balance regional economic inequalities. 